Florida International University FIU Digital Commons

$1-15-2001$

\title{
An approach for clarification of the mechanism of inactivation of ribonucleotide reductases with $3^{\prime}<{ }^{17} \mathrm{O}>$-labeled 2'-azido-2'-deoxynucleotides
}

Saiful Mahmud Chowdhury

Florida International University

DOI: $10.25148 /$ etd.FI14060821

Follow this and additional works at: https://digitalcommons.fiu.edu/etd

Part of the Chemistry Commons

\section{Recommended Citation}

Chowdhury, Saiful Mahmud, "An approach for clarification of the mechanism of inactivation of ribonucleotide reductases with $3^{\prime}<{ }^{17} \mathrm{O}>$-labeled 2'-azido-2'-deoxynucleotides" (2001). FIU Electronic Theses and Dissertations. 2350.

https://digitalcommons.fiu.edu/etd/2350 
FLORIDA INTERNATIONAL UNIVERSITY

Miami, Florida

\begin{abstract}
AN APPROACH FOR CLARIFICATION OF THE MECHANISM OF
INACTIVATION OF RIBONUCLEOTIDE REDUCTASES WITH

3' $\left[{ }^{17}\right.$ O]-LABELED 2'-AZIDO-2'-DEOXYNUCLEOTIDES
\end{abstract}

A thesis submitted in partial fulfillment of the

requirements for the degree of

MASTER OF SCIENCE

in

CHEMISTRY

by

Saiful Mahmud Chowdhury

2001 
To: Dean Arthur W. Herriott

College of Arts and Sciences

This thesis written by Saiful Mahmud Chowdhury, and entitled An Approach for Clarification of the Mechanism of Inactivation of Ribonucleotide Reductases with $3^{3}\left[{ }^{17} \mathrm{O}\right]$-Labeled 2'-Azido-2'-Deoxynucleotides, having been approved in respect to style and intellectual content, is referred to you for judgment.

We have read this thesis and recommend that it be approved.

Dr. Kevin O' Shea

Dr. Leonard Keller

Dr. Stanislaw F. Wnuk, Major Professor

Date of Defense: January 15, 2001

The thesis of Saiful Mahmud Chowdhury is approved.

Dean Arthur W. Herriott College of Arts and Sciences

Interim Dean Samuel S. Shapiro

Division of Graduate Studies

Florida International University, 2001 
DEDICATION

TO MY PARENTS 


\section{ACKNOWLEDGMENTS}

I would like to express utmost appreciation and gratitude to my advisor, Dr. Stanislaw F. Wnuk, (Associate Professor, Department of Chemistry at Florida International University) for his scholastic, inspirational and insightful guidance, as well as advice from the beginning to the end of this thesis work.

I am also much indebted to Mr. Pedro I. Garcia, Jr. for his great help in performing the last two steps of synthesis.

I would like to thank my committee members, Dr. Leonard Keller and Dr. Kevin O'Shea, whose scholastic guidance greatly enriched this thesis work.

My sincerest gratitude and profound thanks also goes to Mr. Alberto J. Sabucedo, for his cooperation and help in performing Mass Spectrometry analysis.

I would also like to thank my co-workers, Carlos Valdez, Neida Valdez, Luis Bergolla, Dania Companioni and Pablo Sacasa for giving me a great laboratory environment during my work and thesis writings.

Finally I would specially thank Dr. Martin Quirke, Dr. Raman Lopez De La Vega and Dr. Yong Cai for their encouragement and advice during my graduate study in Florida International University. 


\begin{abstract}
OF THE THESIS
AN APPROACH FOR CLARIFICATION OF THE MECHANISM OF

INACTIVATION OF RIBONUCLEOTIDE REDUCTASES WITH

3'[ ${ }^{17}$ O]-LABELED 2'-AZIDO-2'-DEOXYNUCLEOTIDES
\end{abstract}

by

Saiful Mahmud Chowdhury

Florida International University, 2001

Miami, Florida

Professor Stanislaw F. Wnuk, Major Professor

Inactivation of ribonucleotide reductases by 2 -azido-2'-deoxynucleotides is accompanied by appearance of new EPR signals for a nitrogen-centered radical. The structure of this elusive nitrogen-centered radical has been studied extensively and shown to be derived from azide moiety. Synthesis of 3 '[ $\left.{ }^{17} \mathrm{O}\right]$-labeled 2'-azido-2'-deoxyuridine-5'diphosphate was targeted in this research. Such a labeled analogue should perturb the EPR spectrum in predictable fashion, and the hyperfine interaction between the free electron and the ${ }^{17} \mathrm{O}$ nucleus should allow the choice between the recently proposed structures of this elusive radical (Van Der Donk, W. A. et al. J. Am. Chem. Soc. 1995, 117, 8908-8916).

The labeled 2'-azido-2'-deoxynucleotides was prepared by thermolysis of $O^{2}, 3^{\prime}$ anhydrouridine to give the more stable $O^{2}, 2^{\prime}$-anhydrouridine derivatives with concomitant rearrangement of the $2^{\prime}-O$-benzoyl $\left[{ }^{17} \mathrm{O}\right]$ group into the $3^{\prime}-\left[{ }^{17} \mathrm{O}\right]$-benzoyl 
intermediate. Deprotection and ring opening with $\mathrm{LiF} / \mathrm{Me}_{3} \mathrm{SiN}_{3}$ gave the $3^{\prime}\left[{ }^{17} \mathrm{O}\right]-2^{\prime}$-azido $2^{\prime}$-deoxyuridine. Tosylation (O5') and displacement of the $5^{\prime}$-tosylate by treatment with tris(tetra-n-butylammonium) hydrogen pyrophosphate gave $3^{\prime}\left[{ }^{17} O\right]-2^{\prime}$-azido-2'deoxyuridine 5'-diphosphate. All the intermediates and the products were characterized by ${ }^{1} \mathrm{H}-\mathrm{NMR},{ }^{13} \mathrm{C}-\mathrm{NMR},{ }^{31} \mathrm{P}-\mathrm{NMR}$ and isotopic enhancement was confirmed by using mass spectrometry. 
CHAPTER

PAGE

1. INTRODUCTION

1

1.1 General Introduction..........................................................

1.2 Ribonucleotide Reductases..........................................6

1.2.1. Structure of Ribonucleoside Diphosphate Reductase.. ...................9

1.2.2. Mechanism of Action of RDPR .................................. 11

1.2.3. Inhibition of RDPR ...............................................

1.2.4. Proposed Mechanism of Inhibition of RDPR by 2'-Azido-2'-

deoxyuridine 5 '-diphosphate................................... 17

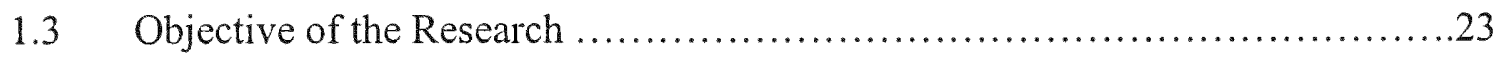

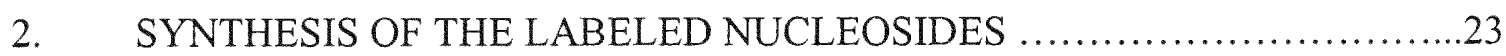

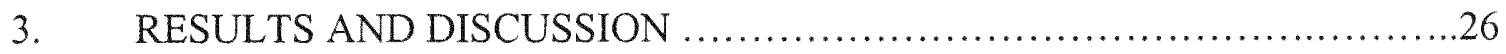

3.1 Designing the Synthesis of 3'-Oxygen Labeled Compounds ....................26

3.2 Stereoselective Introduction of the Labeled Oxygen at the 3'-Position Via

Fox Rearrangement................................................. 28

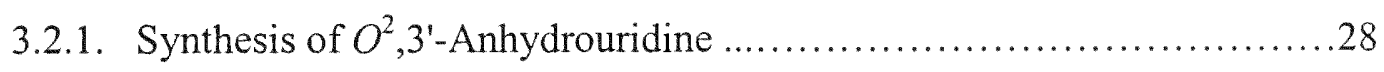

3.2.2. Synthesis of Oxygen Labeled Benzoyl Chloride ........................29

3.2.3. Rearrangement of $2 '-O$-Benzoyl Compounds ....................... 32

3.3 Synthesis of 2'-Azido-2'-deoxynucleotides.................................. 35

3.4 Preparation of $2^{\prime}$-Azido-2'-deoxy-3'- ${ }^{17} \mathrm{O}$-uridine $5^{\prime}$-diphosphate................38 


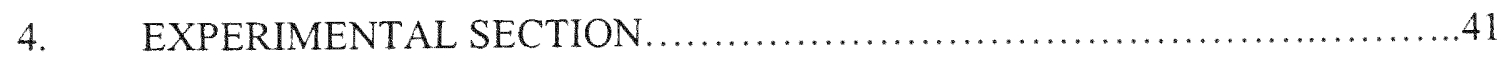

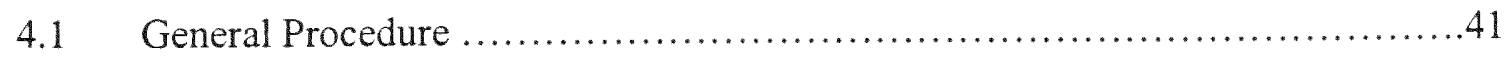

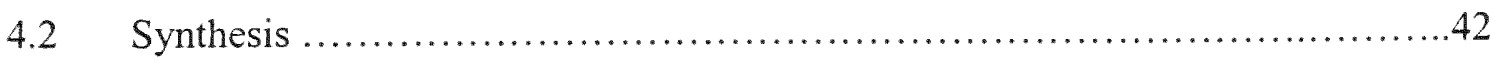

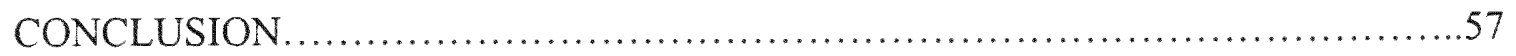

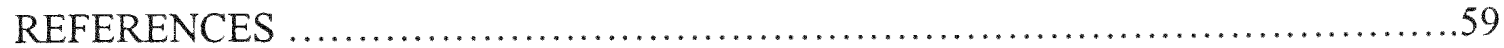




\section{LIST OF SCHEMES}

SCHEME

PAGE

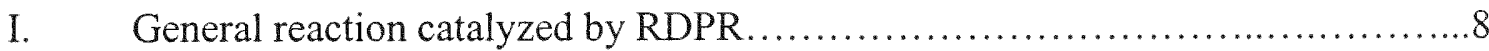

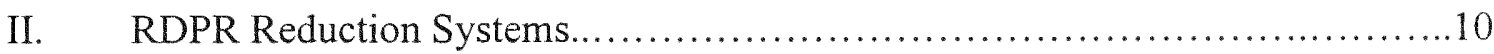

III. Postulated RDPR Radical Mechanisms...................................13

IV. A Generalized View of Mechanism of Inhibition of RDPR by

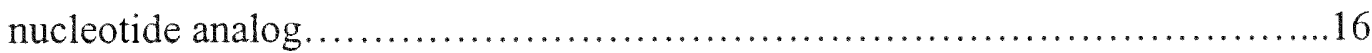

V. Proposed Mechanism of Inactivation of RDPR by 2'-Azido-2'-

deoxyuridine 5 '-Diphosphate by Salowe, et al ..............................19

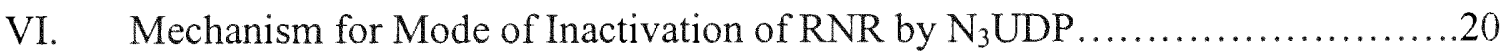

VII. Proposed Structures of Nitrogen-Centered Radical by Vander Donk,

et al

VIII. A General Method the Synthesis of Specifically Labeled Pyrimidine

Nucleosides by Schram, et al .....................................25

IX. Synthesis of 3'-Oxygen-labeled Nucleoside by McCloskey, et al..............27

X. Synthesis of $O^{2}, 3^{\prime}$-Anhydrouridine ...................................... 30

XI. Synthesis of 2'-O-Benzoyl Compounds................................. 31

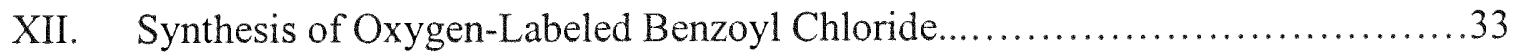

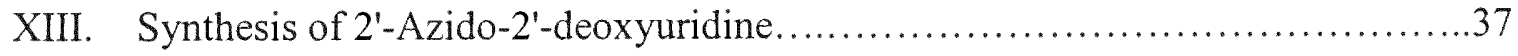

XIV. Preparation of 2'-Azido-2'-deoxy-3'- ${ }^{17} \mathrm{O}$-Uridine 5'-Diphosphate...............40 


\section{INTRODUCTION}

\subsection{GENERAL INTRODUCTION}

One of the major scientific achievements of the twentieth century has been the identification, at the molecular level, of the chemical interactions that are involved in the transfer of genetic information and the control of protein biosynthesis. The substances involved are biological macromolecules called nucleic acids. The history of the determination of the structure and function of nucleic acids began in 1868 when F. Miesher ' isolated a material rich in phosphorus from the nuclei of pus cells and from the sperm of a salmon. Miesher later found that this material is a common constituent of yeast, kidney liver, testicular, and nucleated red blood cells. He named this material nuclein. It was later named nucleic acid by Altmann. ${ }^{2}$

The two major types of nucleic acids are named ribonucleic acid (RNA) and deoxyribonucleic acid (DNA). DNA and some RNA are very large polymeric molecules of high molecular weight, which preserve hereditary information that is transcribed and translated in a way that allows the synthesis of all of the various proteins in the cell. The genetic message is transcribed from DNA onto a form of RNA called messenger RNA (mRNA). This messenger RNA acts as a template for protein synthesis. ${ }^{3,4}$

Nucleic acids are long, thread-like polymers made up of a linear array of monomers called nucleotides. Different nucleic acids can have from around 80 nucleotides, as in transfer RNA, to over $10^{8}$ nucleotide pairs as in a single eukaryotic chromosome. ${ }^{5}$ The unit size of a nucleic acid is called a base pair (for double-stranded 
species) and a base (for single-stranded species). The genomic DNA of a single human cell has $3900 \mathrm{Mbp}$ (million base pairs) and is $990 \mathrm{~mm}$ long.

Mild degradation of nucleic acids yields their monomeric units, a mixture of phosphate esters called nucleotides. These are components of both ribonucleic acid (RNA) and deoxyribonucleic acid (DNA). RNA is made up of ribonucleotides while the monomers of DNA are called 2'-deoxyribonucleotides. Removal of the phosphate group from nucleotides converts them into compounds known as nucleosides.

All nucleotides are constructed from three components: a nitrogen heterocyclic base, a pentose sugar, and a phosphate residue. The major bases are monocyclic pyrimidines or bicyclic purines. The major bases obtained from DNA are the purines, adenine (A) 1 and guanine (G) 2, and the pyrimidines cytosine (C) 3, thymine (T) 4 . RNA bases are mainly adenine, guanine, cytosine, and another pyrimidine base, uracil (U) 5 (Figure 1). In nucleosides and nucleotides, the purine or pyrimidine base is joined from the ring nitrogen to carbon-1 of a pentose sugar. The nucleosides, which are found in RNA are named adenosine 6 , guanosine 7 , cytidine 8 , and uridine 10 . In ribonucleic acid (RNA), the pentose is D-ribose which is locked into a five membered furanose ring by a bond from $\mathrm{C}-1$ of the sugar to $\mathrm{N}-1$ of $\mathrm{C}$ or $\mathrm{U}$ or to $\mathrm{N}-9$ of $\mathrm{A}$ or $\mathrm{G}$. In DNA, the pentose is 2-deoxy-D-ribose and the four nucleosides are 2'-deoxyadenosine 11, 2'deoxyguanosine $12,2^{\prime}$-deoxycytidine 13 , and 2'-deoxythymidine 9.

The phosphate esters of nucleosides are called nucleotides, and the simplest of them have one of the hydroxyl groups of the pentose esterified by a single phosphate monoester function. Adenosine 5'-phosphate $\mathbf{1 4}$ is a $5^{\prime}$-ribonucleotide and is also called adenylic acid (Figure 2). Similarly, 2'-deoxycytidine 3'-phosphate $\mathbf{1 5}$ is a 3 '-deoxy 
<smiles>[R]n1cnc2c(N)ncnc21</smiles>

$1 \mathrm{R}=\mathrm{H}$

$6 \mathrm{R}=\mathrm{R}^{\prime}$

$11 \mathrm{R}=\mathrm{R} "$<smiles>[R]n1ccc(N)nc1=O</smiles>

3. $\mathrm{R}=\mathrm{H}$

$8 \mathrm{R}=\mathrm{R}^{\prime}$

$13 \mathrm{R}=\mathrm{R}^{\prime \prime}$<smiles>[R]n1cnc2c(=O)[nH]c(N)nc21</smiles>

$2 \mathrm{R}=\mathrm{H}$

$7 \mathrm{R}=\mathrm{R}^{\prime}$

$12 \mathrm{R}=\mathrm{R}^{n}$

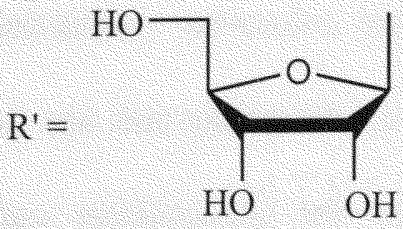

D-RIBOSE

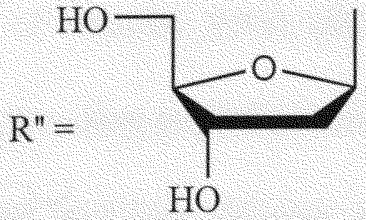

2-DEOXY-D-RIBOSE

Figure 1: Different types of nucleosides 
nucleotide. Nucleotides with two phosphate monoesters on the same sugar are called nucleoside biphosphates (e.g., 16) and a nucleoside monoester of pyrophosphoric acid is called nucleoside diphosphate 17.

The primary structure of DNA has a string of nucleosides, each joined to its two neighbors through phosphodiester linkages. Each regular 5'-hydroxyl group is linked through a phosphate to a 3'-hydroxyl group. The uniqueness of any primary structure depends only on the sequence of bases in the chain. ${ }^{5}$ The secondary structure of DNA was proposed by Watson and $\mathrm{Crick}^{6}$ in 1953 . They proposed a double helix as a model for the secondary structure of DNA. According to this model, two nucleic acid chains are held together by hydrogen bonds between base pairs on opposite strands (e.g., $\mathrm{T}=\mathrm{A}$; $\mathrm{C} \equiv \mathrm{G}$ ). Protein biosynthesis is directed by DNA through the agency of several types of ribonucleic acids called messenger RNA (mRNA), transfer RNA (tRNA), and ribosomal RNA (rRNA). The two main stages in protein biosynthesis are transcription and translation. In the transcription stage, a molecule of mRNA, having a nucleotide sequence complementary to one of the strands of DNA double helix, is constructed. In the translation stage, triplets of nucleotides of mRNA, called codons are recognized by the complementary anticodon base sequences of transfer RNA (tRNA) for a particular amino acid, and that amino acid is added to the growing peptide chain. ${ }^{3,7}$

Since nucleosides are the fundamental building blocks of DNA and RNA, nucleoside analogues have been synthesized as anticancer and antiviral chemotherapeutic agents. These nucleoside analogues have chemical structures slightly different from those of natural nucleosides. If the "foreign" nucleoside is incorporated into the nucleic acid of a cancer cell, it could interfere with the cell metabolism and be fatal to the cell. Viral 


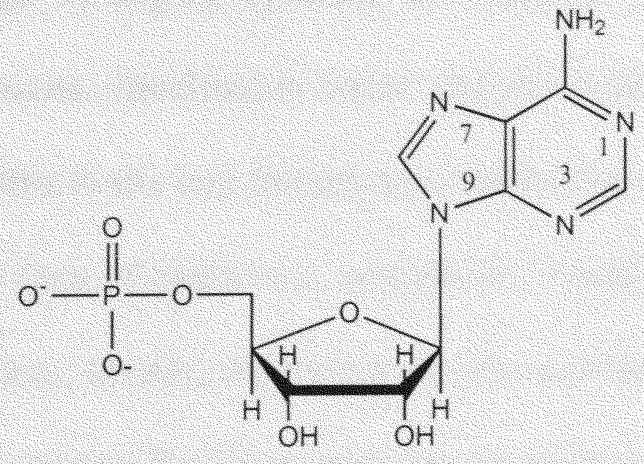

14

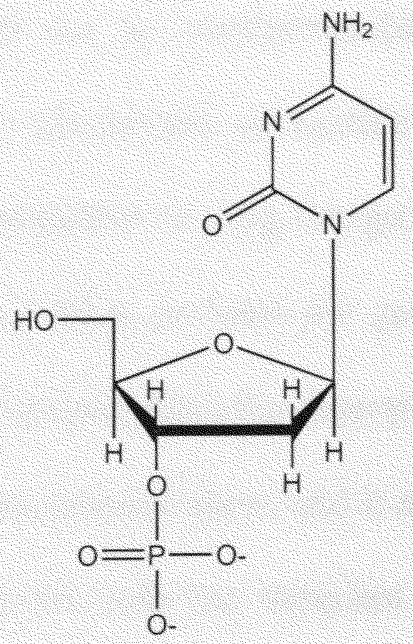

15

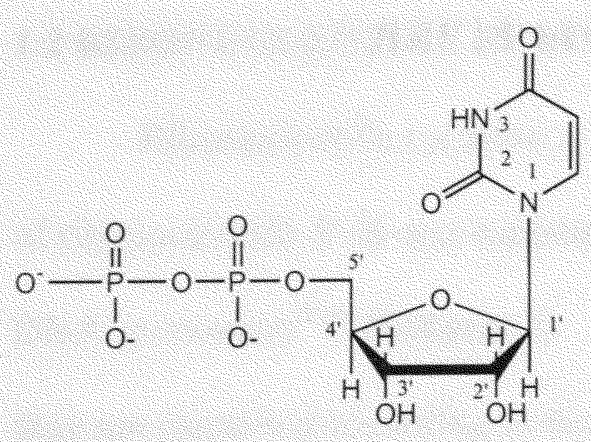

17

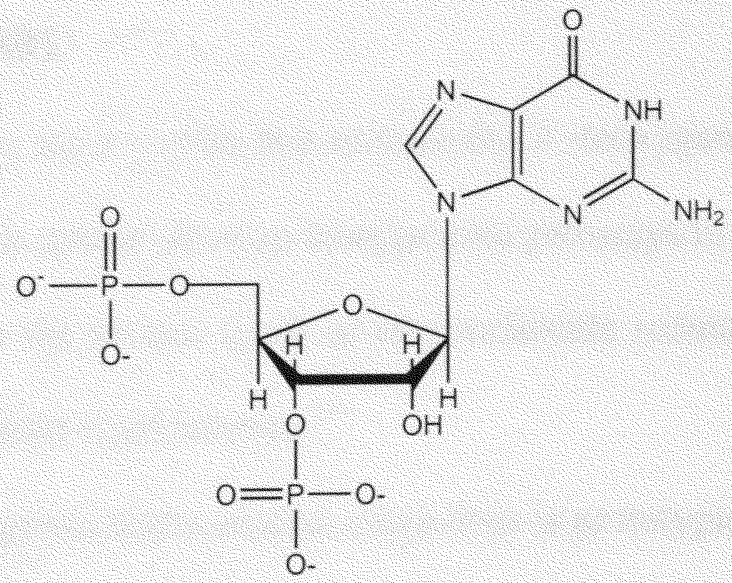

16

Figure 2: Different types of nucleotides 
nucleic acids can be modified in the same way. This antimetabolite approach has stimulated a search for new types of this class of compounds. The second approach is the design of highly specific, low toxicity drugs that act as mechanism-based enzyme inhibitors. Mechanism-based enzyme inhibitors are chemically unreactive compounds, and this is the key feature that makes the drug so amenable to drug design. ${ }^{8}$ Because of their lack of reactivity, nonspecific modifications of other proteins are generally not a problem. Ideally, one target enzyme will be capable of catalyzing the appropriate reaction that converts the mechanism-based inactivator into its reactive form, and it also will have an appropriately juxtaposed nucleophile that can react with the incipient electrophilic center. $^{8}$

\subsection{RIBONUCLEOTIDE REDUCTASES}

Ribonucleotide reductases (RNRs) are enzymes that execute the 2'-deoxygenation of ribonucleotide 5'-di-and triphosphate in unique de novo biosynthesis pathways to form DNA monomers ${ }^{9,10}$ (Scheme I). There are several types of ribonucleotide reductases; they are classified according to their cofactor requirements. ${ }^{11}$

The RNR isolated from bacteria grown under aerobic conditions is prototypical of the Class I RNRs, which also include mammalian and herpes simplex virus (HSV) RNRs. This enzyme uses ribonucleotide diphosphate (RDPR) as the substrate. It is composed of two homodimeric subunits, R1 and R2. The R2 subunit contains a cofactor, which is composed of an unusual $\mu$-oxo-bridged diferric cluster adjacent to a tyrosyl radical $(\bullet$ Tyr 122 in Escherichia coli). The tyrosyl radical is essential for catalysis and is generated by the diferrous form of $\mathrm{R} 2$ in the presence of molecular oxygen. 
The RNR isolated from Lactobacillus leichmannii (class II) requires adenosyl cobalamin $(A d o c b l=$ coenzyme B12) as a radical generated cofactor. These enzymes use ribonucleotide triphosphate $(R T P R)$ as substrate. $R T P R$ is a single polypeptide $\left(M_{r}=76\right.$ kda), which catalyzes the conversion of nucleotide triphosphates (NTPs) to 2'deoxynucleotide triphosphate (dNTPs) with concomitant oxidation of two active sites of thiols to disulfides.

The RNR isolated from $E$. coli grown under anaerobic conditions (class III) is distinct from the enzyme produced under aerobic conditions (class I). When isolated, it is proved to have an essential glycyl radical, which is generated by the second subunit of the enzyme that is equivalent to $\mathrm{R} 2$ in the aerobic $E$. coli $\mathrm{RNR}$. The activating enzyme requires $S$-adenosylmethionine and an iron-sulfur cluster to generate the glycyl radical via a novel mechanism.

The RNR from Brevibacterium ammoniagenes (which is considered as class IV) has been recently characterized. It is thought to possess an $\alpha_{2} \beta$ subunit structure and a dinuclear $\mathrm{Mn}^{3+}$ cluster analogous to the diferric cluster of aerobic E.coli RNR. This class of enzymes is poorly understood.

Despite the dramatic differences in these reductases (Figure 3), ${ }^{11}$ their mechanisms unusual, involving exquisitely controlled radical base chemistry. Each of the metallo-cofactors initiates these radical-dependent nucleotide reduction processes by generating a transient protein radical. The working model is based on the two best characterized RNRs, those from E. coli and L. leichmannii. The function of both the tyrosyl radical (in E. coli) and the adenosylcobalamin radical (in L. leichmannii) is to generate thiyl radical. ${ }^{11,12}$ 

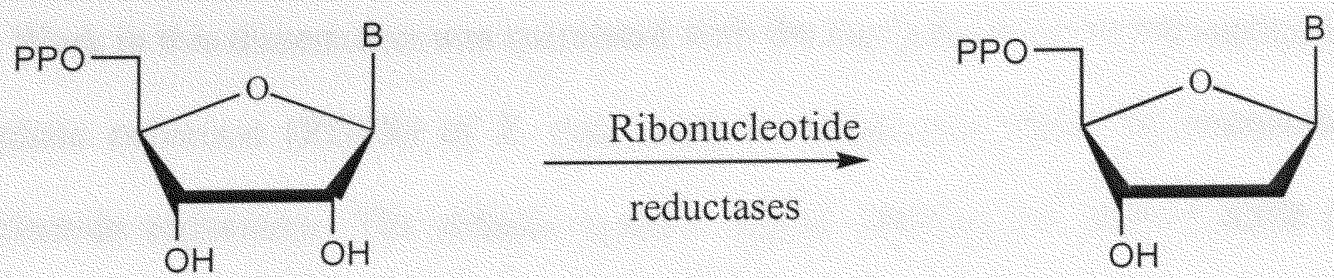

$$
B=A, G, C, U
$$

Scheme I: General reaction catalyzed by RDPR

E. coli, mammalian

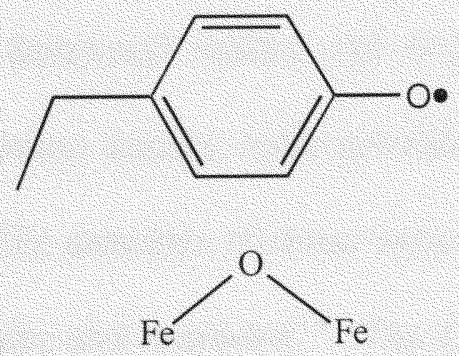

Class 1
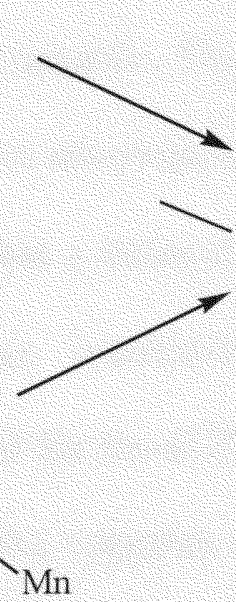

Class IV<smiles>[Mg]O[AlH2]</smiles>

B. ammoniagenes
L. Teichmannii

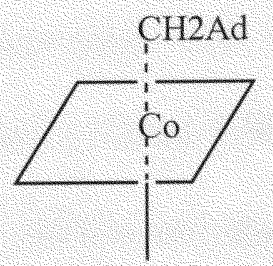

Class II
Thiyl radical<smiles></smiles><smiles>CCCCCCC(C)=O</smiles>

S-adenosylmethionine

FeS cluster

ancierobic E. coli

Figure 3: The cofactors used by four major classes of RNRs 
Work in this dissertation was correlated with the mechanism of the ribonucleoside diphosphate reductase (RDPR) of $E$. coli since it closely resembles the mammalian ribonucleotide reductases. The diferric-tyrosyl radical required by class I RNR are potentially attractive targets for the design of antitumor and antiviral agents. The reminder of this introduction will focus on the structure, mechanism and inhibition of RDPR.

\subsubsection{STRUCTURE OF RDPR}

Structural studies and sequence alignments, in conjunction with chemical and biochemical studies, have provided us with a generic picture of class I RDPR (Figure 4). ${ }^{9-13}$ The structure of these enzymes has been extensively studied and characterized by Thelander and Reichard. ${ }^{14}$ The ribonucleoside diphosphate reductase from Escherichia coli has two nonidentical subunits. They are known as proteins R1 and R2 and exist in a 1:1 complex with the active site proposed to be at the interface of these subunits. Protein $\mathrm{R} 1$ is a dimer $\left(\alpha \alpha^{\prime}\right)$ and has a molecular weight of 160,000 . The functional end of the molecule is the R1 subunit. It contains the binding sites for the purine and pyridimine diphosphate substrates and for the dNTPs and ATP, which act as allosteric effectors. In addition, it contains the five cysteines that are essential for catalysis. Cysteines 225 and 462 are oxidized to the disulfide during nucleotide reduction, thus providing the required reducing equivalents. Cys754 and Cys 759 are at the carboxy-terminal trail of Rl and are not detectable in the X-ray structure due to thermal flexibility. They shuttle reducing equivalents into and out of the active sites via disulfide interchange with thioredoxin 


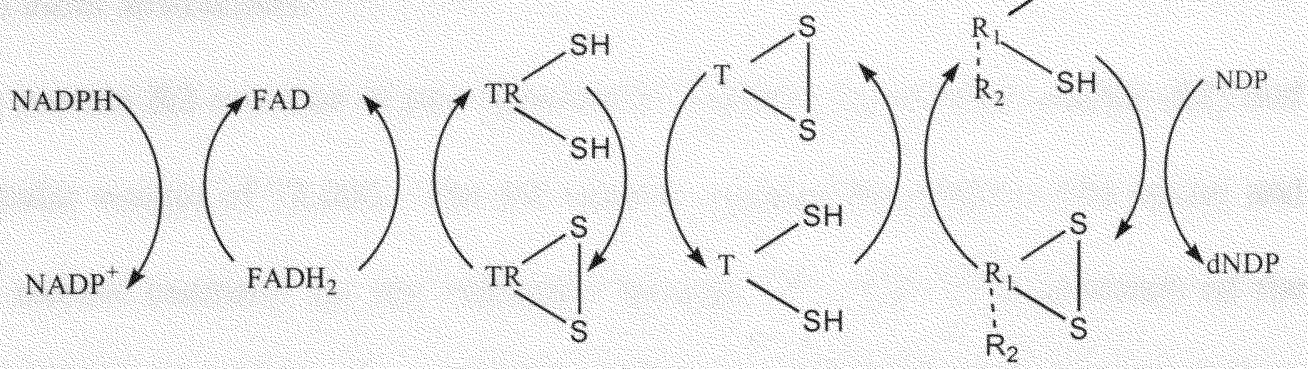

Scheme II: RDPR reduction systems

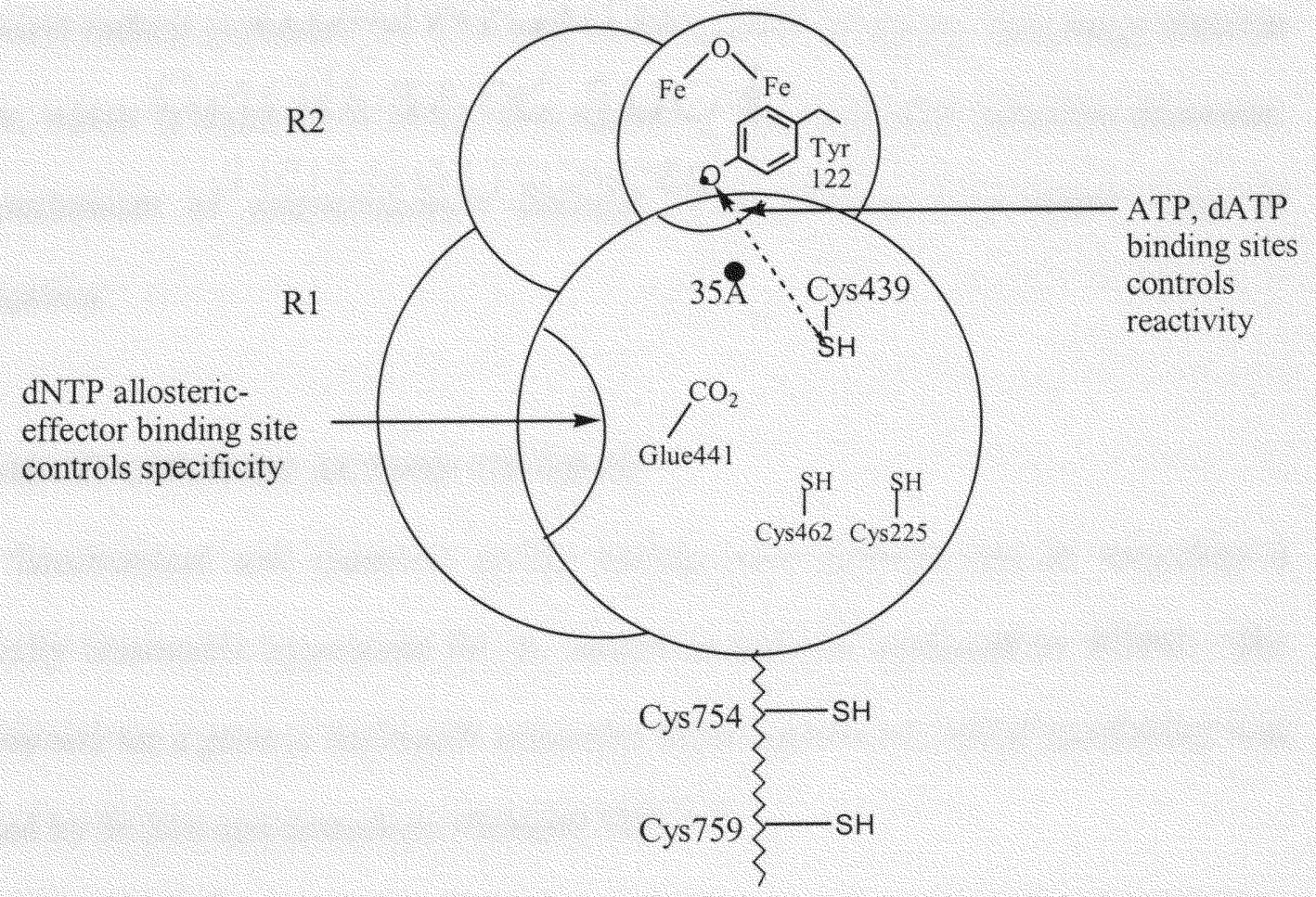

Figure 4: Generic picture of Class I RNR 
Scheme II). The fifth cysteine (Cys439) is proposed to initiate nucleotide reduction by $3^{\prime}$-hydrogen atom abstraction. 11,15

The protein R2 consists of two apparently-identical polypeptide chains $(\beta 2)$ and has a molecular weight of 78,000. The R2 subunit contains the diferric iron center and the tyrosyl radical essential for the reduction process. ${ }^{16,17}$ The EPR spectrum of the tyrosyl radical shows a doublet $(g=2.0047)$, with super imposed hyperfine interaction. The UV-VIS spectrum possesses a sharp absorption at $410 \mathrm{~nm}\left(\varepsilon=3250 \mathrm{M}^{-1} \mathrm{~cm}^{-1}\right)$. This cofactor is buried in $\mathrm{R} 2$, lying $10 \AA$ from the nearest surface. It has been proposed that the tyrosyl radical generates the thiyl radical on Cys 439 of R1 by long-range electron transfer, which is some $35 \AA$ away, thus initiating the nucleotide reduction processes. The mechanism of communication between these subunits is a major focus of investigation.

\subsubsection{MECHANISM OF ACTION OF RDPR}

Biochemical and chemical model studies have allowed one to formulate a chemically reasonable hypothesis for the reduction reaction catalyzed by RDPR. The first proposal for a generic nucleotide reduction which involves a radical mechanism was proposed by Stubbe and coworkers (Scheme III). ${ }^{18,19}$

The first steps in this mechanism involve a protein-mediated hydrogen atom abstraction from the $3^{\prime}$-carbon of NDP to produce a 3 '-nucleotide radical. In the second step, protonation of 2'-OH can be achieved by proton transfer from the active dithiols in the $\mathrm{R} 1$ subunit. This would facilitate the cleavage of the $\mathrm{C} 2{ }^{\prime}-\mathrm{OH}$ bond and result in formation of a radical cation. After loss of water, the two cysteines on the $\alpha$ face of the 
nucleotides (Cys462, Cys225) deliver the required reducing equivalents, generating a 3'radical 2'-deoxynucleotide intermediate. This intermediate is subsequently reduced to give $\mathrm{dNDP}$ and a disulfide with regeneration of the radical initiator for the next turnover of the enzyme.

Two important features of this mechanism are: (1) abstraction of the $\mathrm{H}^{\prime}$ atom which is necessary for the cleavage of the $\mathrm{C} 2^{\prime}-\mathrm{OH}$ bond; (2) the hydrogen, which is abstracted from the $3^{\prime}$ position in the starting materials, is returned to the $3^{\prime}$ position in the products.

These two predictions have been experimentally established. The first prediction is that $\mathrm{C}^{\prime}-\mathrm{H}$ bond of the NDP substrate is cleaved. Use of $\left[3^{\prime}-{ }^{3} \mathrm{H}\right]$ NDPs and measurement of isotope effects where $\mathrm{N}$ is either pyrimidine or purine and with the presence of differing allosteric effectors have unambiguously established that RDPR is capable of catalyzing cleavage of the $\mathrm{C} 3^{\prime}-\mathrm{H}$ bonds. Control experiments using $\left[1^{\prime}-{ }^{3} \mathrm{H}\right]$ and $\left[2^{\prime}-{ }^{3} \mathrm{H}\right]$ NDPs indicate no observable selection effects on RDPR-catalyzed reductions. In addition, reduction of $\left[3^{\prime}-{ }^{2} \mathrm{H}\right]$ UDPs by RDPR shows positive isotopic effects in support of C3'-H cleavage. The second predictions, that hydrogen abstracted from the 3' position in the starting materials is returned to the $3^{\prime}$ position in the dNDP products, were verified by the use of [3'-H] UDP and by analysis of the end-product by NMR.

The main feature of the proposed mechanism is the involvement of a radical intermediate. Experimental efforts to ascertain its intermediacy utilized stopped- flow techniques as well as the premise that $\mathrm{X} \bullet$ (protein radical) is tyrosyl radical 122 . Although the mechanism suggests the feasibility of a radical cation intermediate, no direct evidence for this intermediate exists, and model studies indicated that at least one 

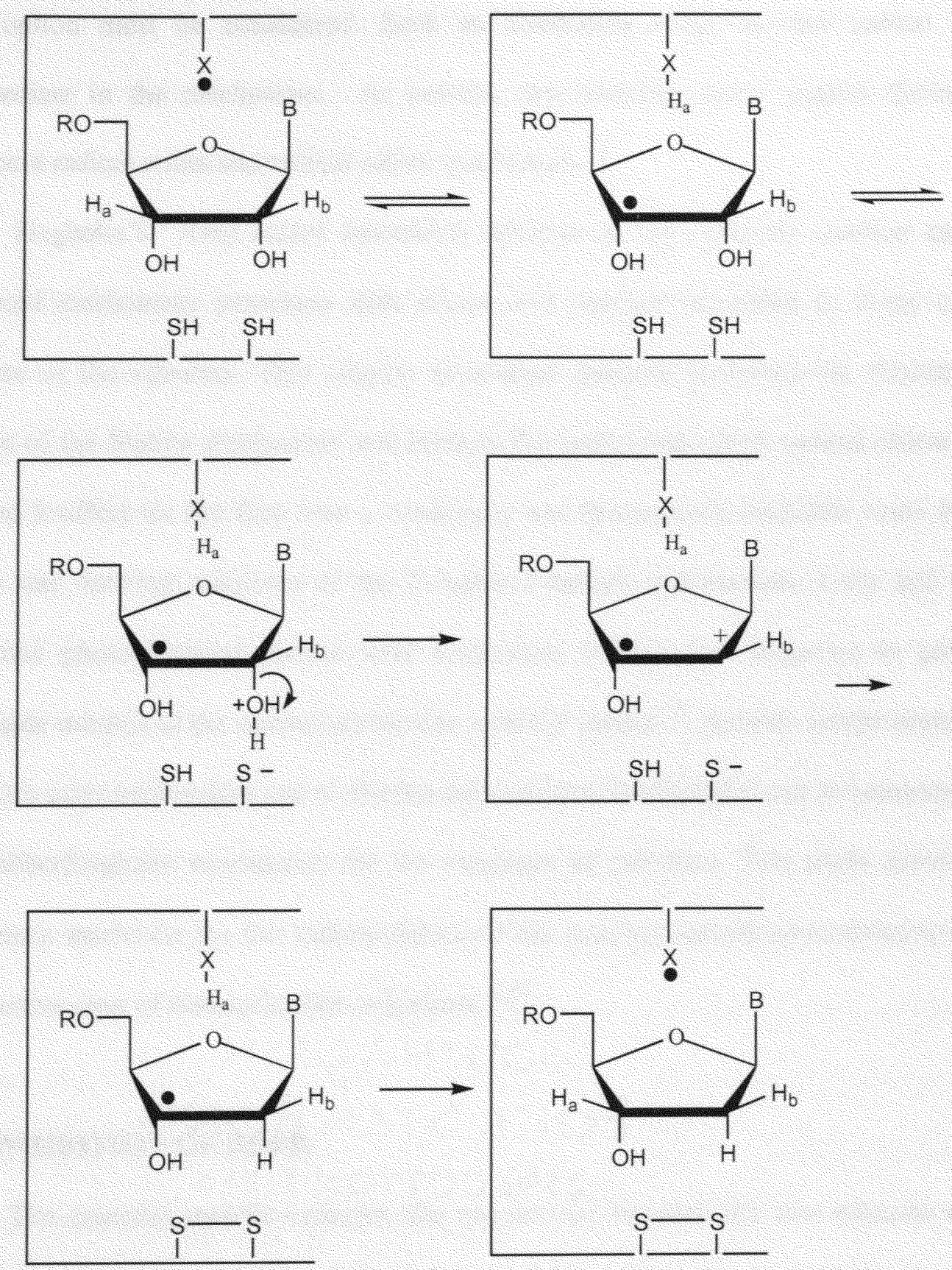

$$
\begin{aligned}
& X=\text { Protein } \\
& R=P P
\end{aligned}
$$

Scheme III: Postulated RDPR radical mechanisms 
other option must be considered. Such an alternative might involve radical anion intermediate in the mechanism. At present, experimental results cannot distinguish between a radical anion and radical cation mechanism. ${ }^{19}$

Siegbahn's ${ }^{20}$ very recent theoretical analysis of the substrate reaction cascade correlated mechanistic processes with amino acid residues identified in X-ray crystal structure of the subunits. This elegant theoretical analysis preserves the fundamental concept of the Stubbe mechanism and corrects the postulated cation radical character at $\mathrm{C} 2$ ', and it offers for the first time a chemically and theoretically plausible route for the overall rate limiting reduction of the 2'-deoxy-3'-ketone intermediate. Lenz and Giese performed photochemical studies with selenoester models that fragment to generate nucleoside mimics of the natural nucleoside with $\mathrm{C} 3$ ' radical. ${ }^{21}$ Another recent study with $5^{\prime}-O$-nitro ester nucleosides and 6'-O-nitro ester of homonucleosides was in harmony with the Stubbe/Siegbahn mechanism for the reduction of substrate. This study provided a biomimetic model for the free radical-induced relay reaction cascades postulated to occur at the active sites of ribonucleotide reductases. ${ }^{22,23}$

\subsubsection{INHIBITION OF RDPR}

The essential metallo-cofactor, the interactions between the two subunits of the class I RNRs, and the unusual radical intermediate in the nucleotide reduction process have all provided proven targets for the design of inhibitors of this essential enzyme.

Three potentially complementary approaches have successfully targeted RNRs in vitro based on the detailed understanding of the biochemistry of this system and of nucleotide metabolism. One involves nucleotide analogs as mechanism-based inhibitors. 
A second involves the reduction of tyrosyl radical required for initiation of nucleotide reduction. The third focuses on the inhibition of the interaction of $\mathrm{R} 1$ and $\mathrm{R} 2$ subunits, both of which are required for nucleotide reduction.

In 1976, Thelander and co-workers reported that 2'-chloro-2'-deoxynucleotides such as ClCDP $\left(X=C l\right.$, Scheme IV) and 2'-azido-2'-deoxunucleotides $\left(X=N_{3}\right.$, Scheme IV) such as $\mathrm{N}_{3} \mathrm{UDP}$ or $\mathrm{N}_{3} \mathrm{CDP}$ are potent inactivators of RDPR. ${ }^{24} \mathrm{~A}$ detailed understanding of the mechanism by which these compounds inactivate the enzyme has evolved since their discovery. ${ }^{11}$

A generalized view of the mechanism responsible for enzyme inactivation by nucleotide analogs is shown in Scheme IV. ${ }^{11}$ The initial steps, as in the case of NDP reduction, is 3'-hydrogen atom abstraction by a thiyl radical at Cys439. Deprotonation of 3'-OH concomitant with removal of leaving group $\mathrm{X}$ results in the formation of a 2 'deoxy-3'-ketonucleotide radical which can then be reduced from the top face ( $\beta$-face) or the bottom face ( $\alpha$-face) of the inhibitor. Reduction from the bottom face by dithiols results ultimately in the inability to regenerate the thiyl radical on Cys439 and hence in the case of $E$. coli $\mathrm{RNR}$, the tyrosyl radical cannot be reformed. Since tyrosyl radical is essential for catalysis, inactivation of $\mathrm{R} 2$ is a major mechanism of RNR inhibition by many nucleotide mechanism based inhibitors.

Reduction from the $\beta$-face by Cys439 results also in the formation 3'-keto-2'deoxynucleotides which dissociate from the active sites and decompose to yield the 2methylene-3(2H)-furanone, which nonspecifically alkylates the R1 subunit of the enzyme, thus inactivating it. The factors that determine whether the reduction occurs from the top face or from the bottom face are not completely understood. 

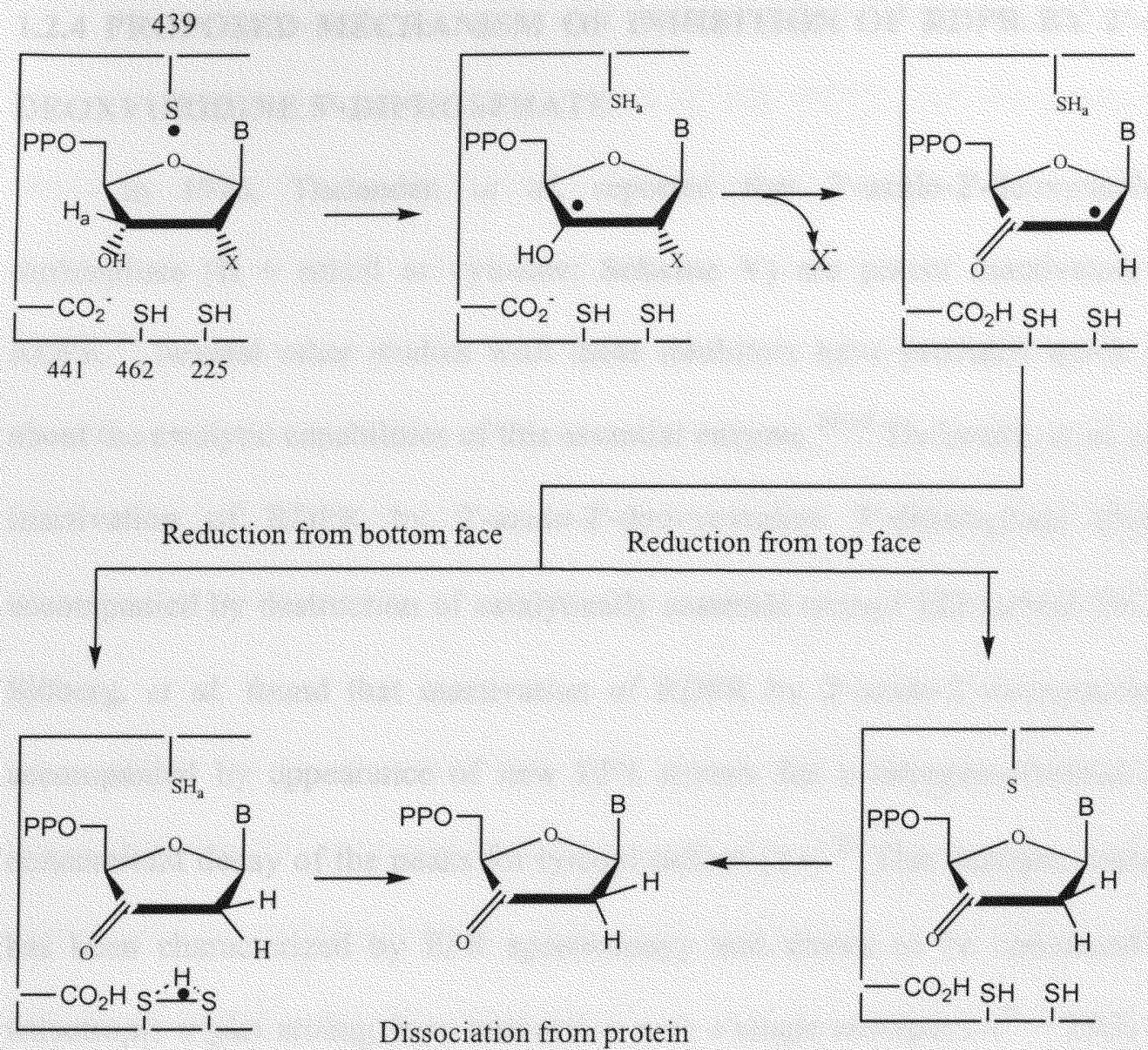

loss of tyrosyl radical
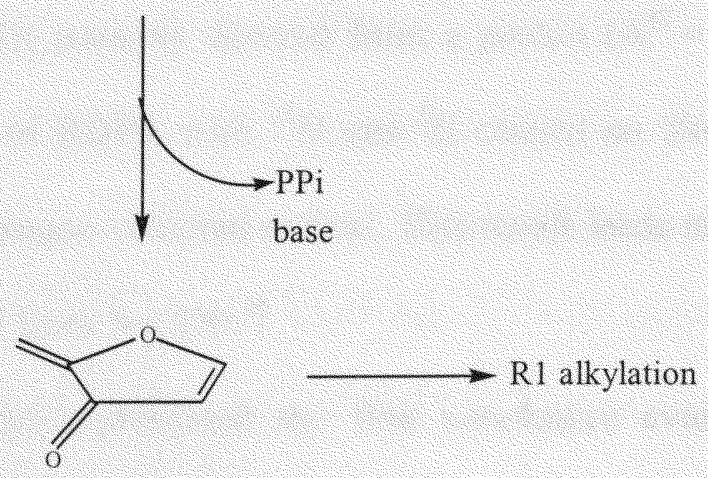

Scheme IV: A generalized view of mechanism of inhibition of RDPR by nucleotide analog 


\subsubsection{PROPOSED MECHANISM OF INHIBITION OF RDPR BY 2'-AZIDO-2'- DEOXYURIDINE 5'-DIPHOSPHATE}

In 1976, Thelander, et al. reported that 2'-azido-2'-deoxynucleosides 5'diphosphate $(\mathrm{B}=$ uracil or cytosine; Scheme $\mathbf{V})$ are potent inactivators of $E$. coli RDPR. ${ }^{24}$ Several other studies with these inhibitors have provided much information about the catalytic capabilities of this essential enzyme. ${ }^{25-30}$ Thelander, et al. reported that inactivation of RDPR by 2'-azido-2'-deoxycytidine 5'-diphosphate $\left(\mathrm{N}_{3} \mathrm{CDP}\right)$ was accompanied by destruction of catalytically essential tyrosyl 122 radical $\mathrm{Y} \bullet{ }^{24}$ In 1983 , Sjöberg, et al. found that inactivation of RDPR by 2'-azido-2'-deoxynucleotides was accompanied by appearance of new EPR signals for a nitrogen-centered radical and concomitant decay of the peaks for tyrosyl radical $(\mathrm{Y} \bullet) .{ }^{25}$ This nitrogen-centered radical has been characterized by EPR spectroscopy and shown to be composed of a 1:1:1 anisotropic triplet arising from interaction with a single nitrogen $\left(A^{N}=25 G\right)$ and second hyperfine interaction doublet possibly derived from a proton $\left(\mathrm{A}^{\mathrm{H}}=6.3 \mathrm{G}\right) .{ }^{25,26}$ Isotopic labeling of the R2 subunit of RDPR with ${ }^{15} \mathrm{~N}$ and ${ }^{2} \mathrm{H}$ caused no alteration of hyperfine interaction with the new nitrogen-centered radical. This result leads to the hypothesis that the new radical was derived from $\mathrm{N}_{3} \mathrm{CDP}^{25}$

Stubbe and co-workers presented the first conclusive evidence that the new radical is derived from azide, since altered splitting of the EPR signal (triplet collapsed to a doublet) was observed upon inactivation of RDPR with $2^{\prime}-\left[{ }^{15} \mathrm{~N}\right] \mathrm{N}_{3} \mathrm{UDP}$. The observation of a substrate-derived radical provided the first direct evidence for free radical chemistry with $R D P R .^{26}$ 
To understand the complex reaction catalyzed by RDPR, specific isotopically labeled $\mathrm{N}_{3} \mathrm{UDP}$ s were prepared and incubated with RDPR, and the products and their stoichiometries were ascertained. It was found that one equivalent of $\mathrm{N}_{3} \mathrm{UDP}$ inactivated one equivalent of RDPR. This inactivation was accompanied by cleavage of the $3^{\prime}$ carbon-hydrogen bond $\left(\mathrm{C}^{\prime}-\mathrm{H}\right)$ and production of one equivalent each of uracil, inorganic pyrophosphate, and molecular nitrogen was observed. No $\mathrm{N}_{3}{ }^{-}$was detected. Incubation of $\left[5^{\prime}-{ }^{3} \mathrm{H}\right] \mathrm{N}_{3} \mathrm{UDP}$ with the protein resulted in covalent modification of the R1 subunit with one equivalent of label, accompanied by a change in absorption of the protein at 320 nm. ${ }^{27}$

These results, in conjunction with EPR studies, allowed the formulation of a model (Scheme V) ${ }^{27}$ proposed by Salowe, et al. in 1987 . These studies, however, were unsuccessful in resolving some the aspects of the mechanism. The identity of the spin $1 / 2$ nucleus responsible for the observed $6.5 \mathrm{G}$ doublet hyperfine interaction with the nitrogen-centered radical $(\mathrm{N} \bullet)$ has remained a mystery but is crucial to defining the structure of the N•. Deuterium labeling experiments, with $\left[{ }^{2} \mathrm{H}\right]$-labeled R2 and with $\mathrm{N}_{3} \mathrm{UDP}\left(\left[^{2} \mathrm{H}\right]\right.$ - labeled at the $1^{\prime}, 2^{\prime}, 3^{\prime}, 4^{\prime}$ positions) have failed to reveal the source of protein hyperfine interaction. ${ }^{25,26,28}$ Doubly-labeled 2 ' $\left[{ }^{15} \mathrm{~N}_{3}\right]-$ azido- $2^{\prime}-\left[{ }^{13} \mathrm{C}\right]-\mathrm{UDP}$ was prepared and incubated with RDPR. ${ }^{28}$ The reaction product was analyzed by EPR and electron spin echo envelope modulation (ESEEM) spectroscopy. It was found that the spectrum of the resulting nitrogen-centered radical has no hyperfine interaction with the $\mathrm{C} 13$ nucleus, which requires cleavage of $\mathrm{C} 2$ '-nitrogen bond.

Based on this experimental data, a new mechanism of inactivation was formulated (Scheme VI). ${ }^{28}$ The inactivation process is assumed to be initiated by $3^{\prime}$ carbon-hydrogen 

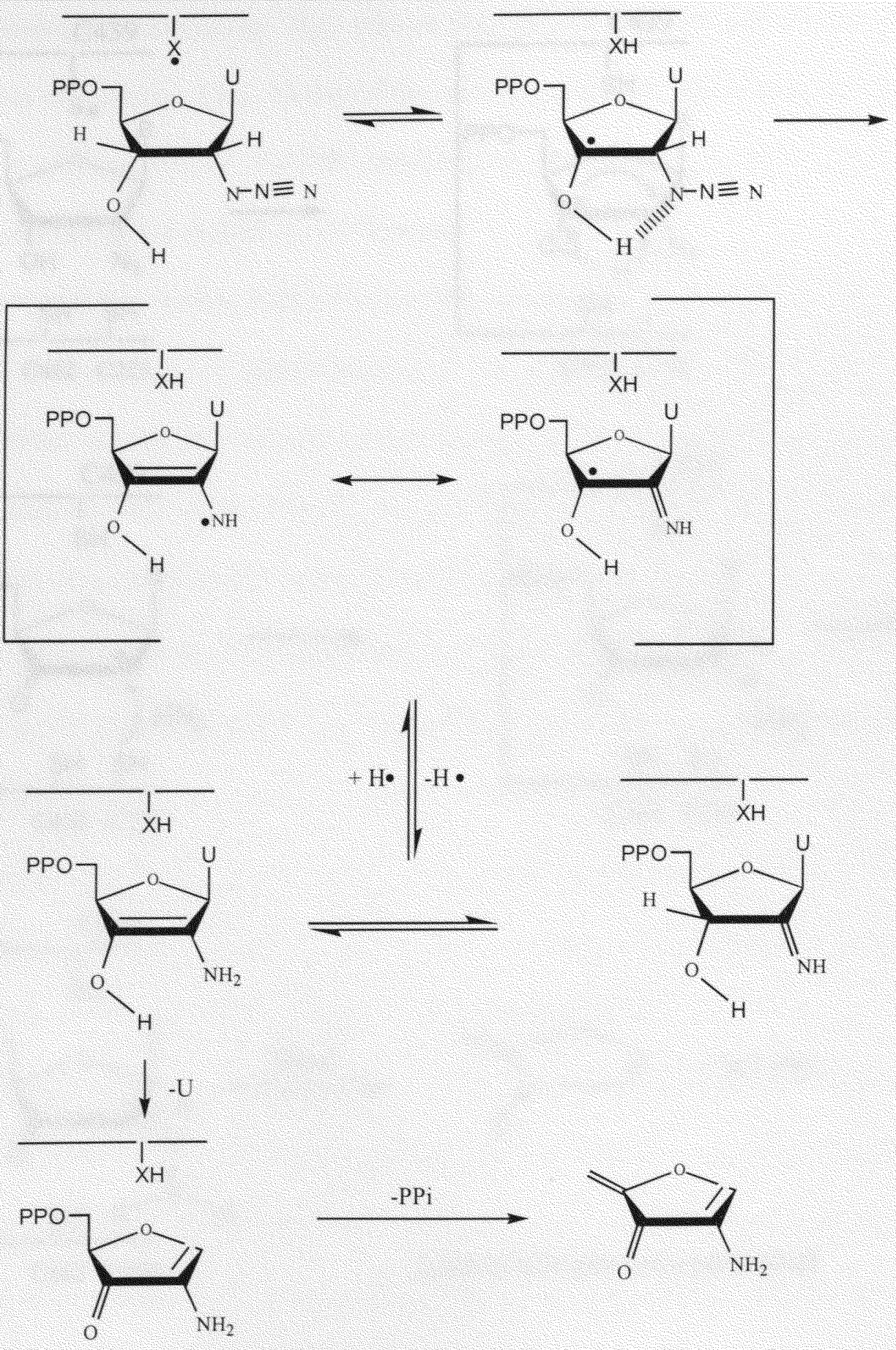

Scheme V: Proposed mechanism of inactivation of RDPR by $\mathrm{N}_{3} \mathrm{UDP}$ by Salowe, et al. ${ }^{27}$ 

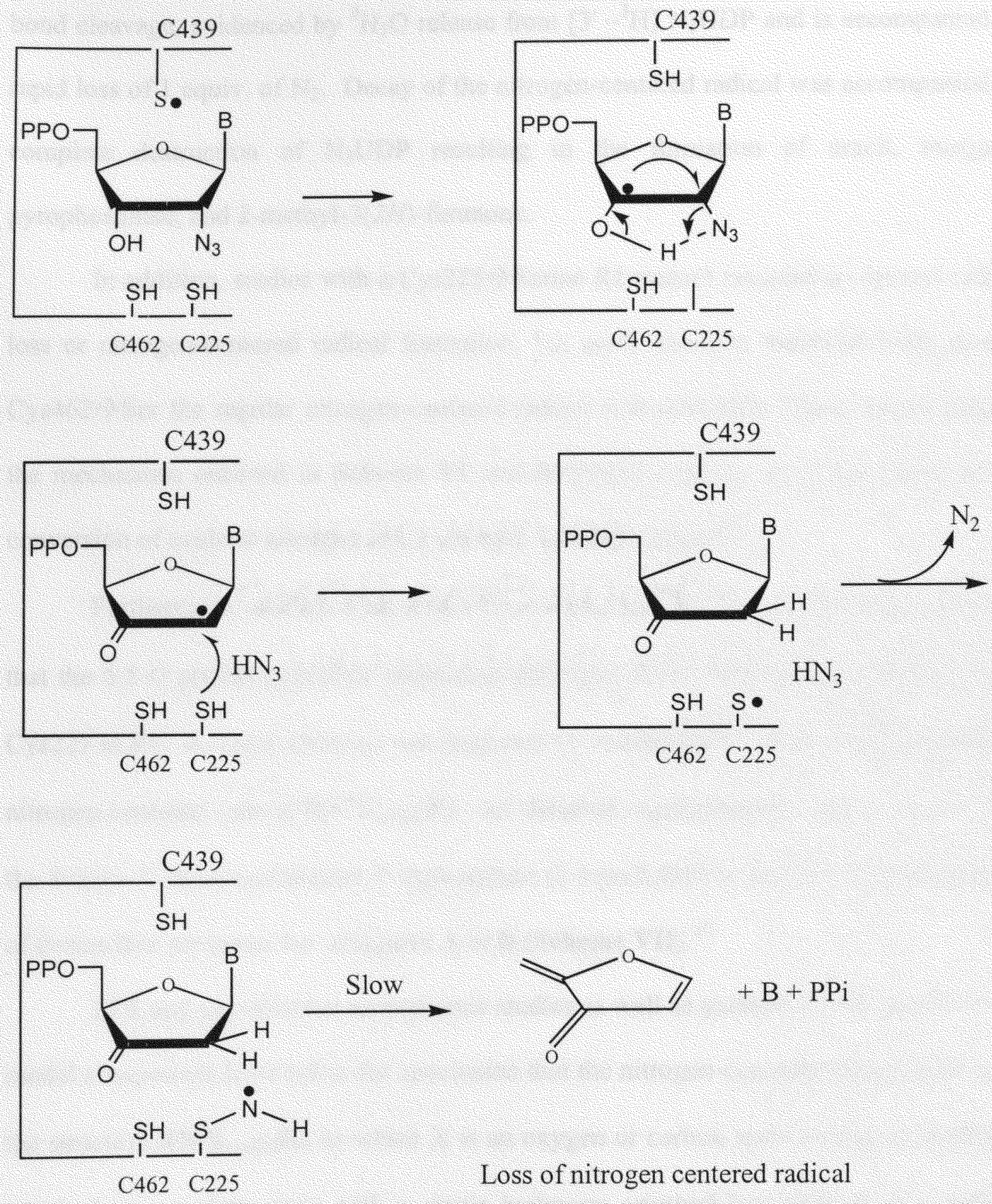

Loss of nitrogen centered radical

Scheme VI: Mechanism for mode of inactivation of RNR by $\mathrm{N}_{3}$ UDP 
bond cleavage, evidenced by ${ }^{3} \mathrm{H}_{2} \mathrm{O}$ release from $\left[3^{\prime}-{ }^{3} \mathrm{H}\right] \mathrm{N}_{3} \mathrm{UDP}$ and is accompanied by rapid loss of 1 equiv. of $N_{2}$. Decay of the nitrogen-centered radical was accompanied by complete destruction of $\mathrm{N}_{3} \mathrm{UDP}$ resulting in the formation of uracil, inorganic pyrophosphate, and 2-methyl-3(2H)-furanone.

In addition, studies with a Cys225 $\rightarrow$ Serine $\mathrm{R} 1$ mutant revealed no tyrosyl radical loss or nitrogen-centered radical formation, but azide ion was observed (with mutant Cys $462 \rightarrow$ Ser the regular nitrogen-centered radical was detected). These results support the mechanism outlined in Scheme VI and implicates Cys225 as a key player in the conversion of azide to nitrogen and a nitrogen-centered radical. ${ }^{30}$

Furthermore, studies with a $\left[\beta-{ }^{2} \mathrm{H}\right]$-cysteine labeled $\mathrm{R} 1$ subunit have indicated that the $6.5 \mathrm{G}$ proton hyperfine interaction observed results from a $\beta$-hydrogen from of Cys225 in R1. A novel structure was proposed by Vander Donk, et al. in which an initial nitrogen-centered radical $\mathbf{H N}^{\bullet} \mathbf{S}_{\mathbf{c y s} 225} \mathbf{R} 1$, not detected experimentally, reacts further with the 3'-keto-2'-deoxynucleotides 5'-diphosphate (3-ketodUDP) to produce a new sequence of events that generates the structures A or B (Scheme VII). ${ }^{30}$

EPR and site-directed mutagenesis studies as well as published EPR results of the model compounds have led to the conclusion that the nitrogen-centered radical must have the structure $\mathrm{XN}^{\bullet} \mathrm{S}_{\mathrm{cys225}} \mathbf{R} \mathbf{1}$ in which $\mathrm{X}$ is an oxygen or carbon atom having no hydrogen attached or a carbon atom with a single hydrogen attached but oriented in a defined fashion. Vander Donk, et al. postulated that $\mathrm{XN}^{\bullet} \mathrm{S}_{\mathrm{cys225}} \mathrm{R} 1$ radical is sitting on the $\alpha$ face of the carbonyl group of the 3'-ketoUDP and that it can interact with the carbonyl of this ketone to generate either compound A or compound B (Scheme VII). Molecular modeling studies indicate that the distance between the $2^{\prime}$-proton and nitrogen in structure 

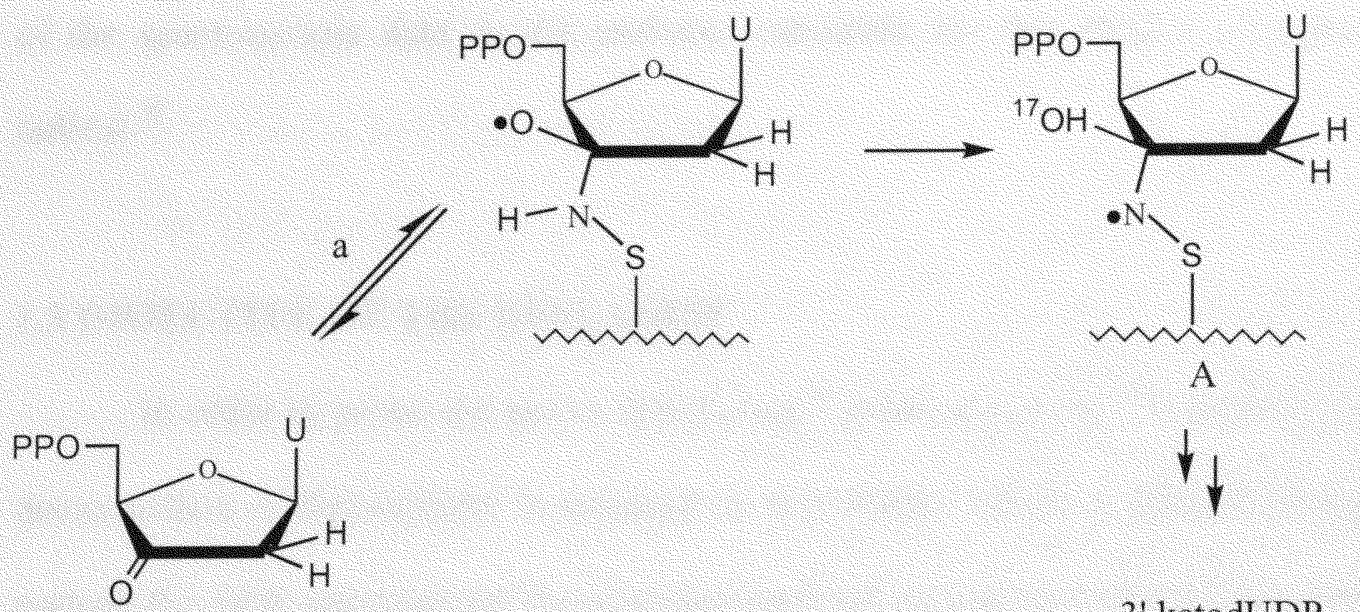

3'-ketoUDP
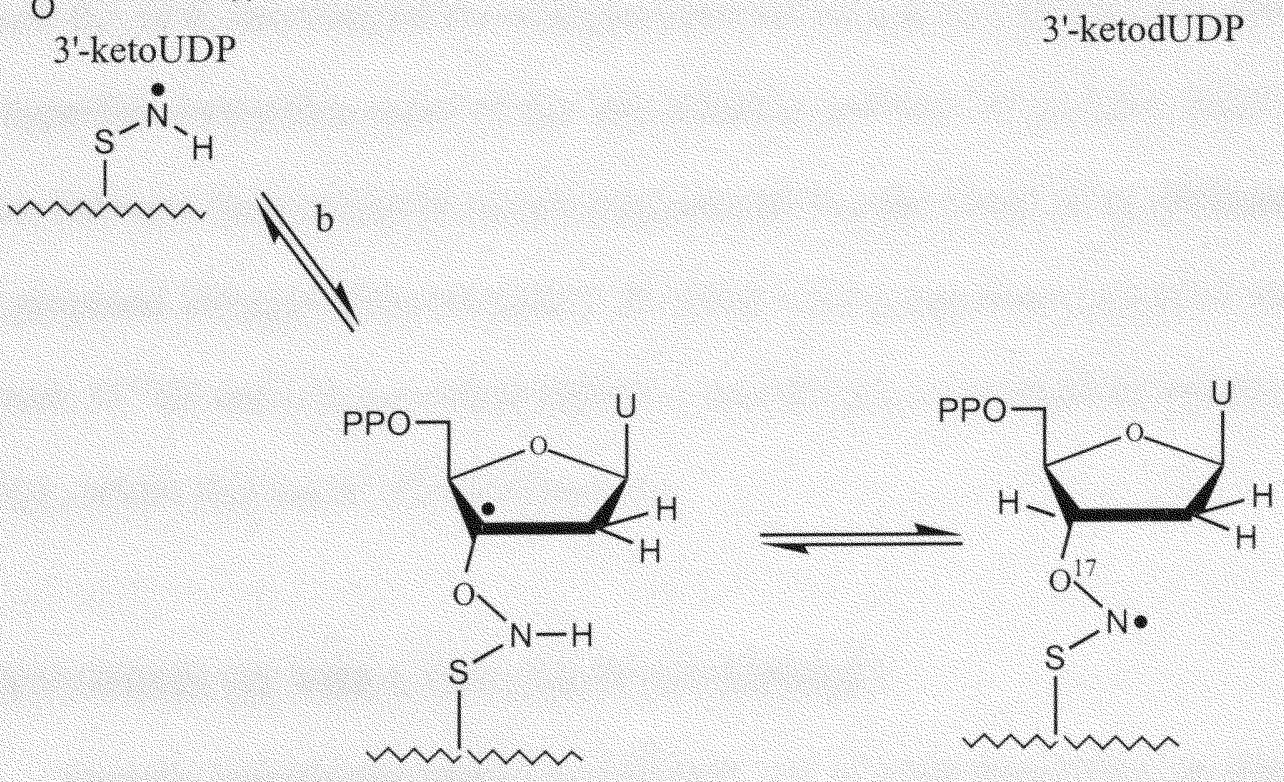

B

Scheme VII: Proposed structures of nitrogen-centered radical by Vander Donk, et al. ${ }^{30}$ 
A must be $<5 \AA$. Electron spin echo envelope modulation (ESEEM) spectroscopy confirmed that structure A, while chemically appealing, is not a viable candidate for nitrogen-based radical. Vander Donk, et al. proposed that structure $\mathbf{B}$, which explains all of the spectroscopic data, is the probable candidate for this elusive nitrogen-centered radical. ${ }^{30}$

\subsection{OBJECTIVE OF THE RESEARCH}

In order to probe the above hypothesis, ${ }^{30}$ synthesis of $3^{2}\left[{ }^{17} \mathrm{O}\right]$-labeled $2^{2}$-azido-2'deoxyuridine 5'-diphosphate is targeted in this study. Such a labeled analog should perturb the EPR spectrum of the nitrogen-centered radical in a predictable fashion, and the hyperfine interaction between the free electron and the ${ }^{17} \mathrm{O}$ nucleus should allow a choice between the recently proposed structures of Vander Donk, et al. (Scheme VII). ${ }^{30}$ The proposed nitrogen-centered radical $\mathbf{B}$ would have a one bond hyperfine interaction between $3{ }^{1}\left[{ }^{17} \mathrm{O}\right]$ and nitrogen while radical $\mathbf{A}$ would have a two bond interaction with the $3^{1}\left[{ }^{17} \mathrm{O}\right]$, which also has a ${ }^{17} \mathrm{O}-{ }^{1} \mathrm{H}$ interaction.

\section{SYNTHESIS OF THE LABELED NUCLEOSIDES}

Specific isotopically labeled compounds are of great importance in studying the biochemistry and the metabolism of both naturally-occurring and synthetic nucleosides of clinical importance. A literature survey indicates that there is a lack of a general procedure for the incorporation of stable isotopes in nucleic acid components. Although synthetic methods describing the incorporation of 18-oxygen and deuterium labeled into the heterocyclic portion of nucleosides have been reported, procedures for labeling the 
sugar moiety have been limited. ${ }^{31,32}$ Anhydronucleosides have been shown to be versatile intermediates for the synthesis and the interconversion of pyrimidine nucleosides. Unfortunately, most ring opening reactions of anhydropyrimidine nucleosides result in the formation of pentofuranosides possessing the arabino or xylo configuration rather then the desired ribo isomer. ${ }^{33}$

The first general approach for the synthesis of specifically-labeled pyrimidine nucleosides was reported by Schram, et al ${ }^{34}$ A facile method for the synthesis of highly enriched ${ }^{18} \mathrm{O}$-labeled pyridimine ribonucleotide was described using uridine as the precursor. The isotopic label was selectively incorporated into $O^{2}$ of the uracil moiety and ribo portion of the molecule at the 5'-position. This methodology is outlined in Scheme VIII. ${ }^{34}$

Basic hydrolysis of the $O^{2}, 5^{\prime}$-anhydro bridge in $\mathbf{1 8}$ with $\mathrm{Na}^{18} \mathrm{OH}$ proceeds by nucleophilic attack specifically at the $\mathrm{C} 2$ position of the heterocyclic base to afford $\mathbf{1 9}$ which was then deprotected to give $20 .{ }^{34}$ Reformation of the $O^{2}, 5^{\prime}$-anhydro bridge by reaction of 19 with triphenylphosphine and diethyl azodicarboxylate (DEAD) provided the key intermediate compound 21. Treatment of 21 with unlabeled $\mathrm{NaOH}$ resulted in cleavage of the anhydro linkage with the ${ }^{18} \mathrm{O}$-label attached directly to the 5 '-position to give 22. Deprotection of 22 yielded $5^{\prime}\left[{ }^{18} \mathrm{O}\right]$-uridine 23. Alternatively, the $2,5^{\prime}$-anhydro bond was cleaved with $\mathrm{Na}^{18} \mathrm{OH}$ with the resultant incorporation of a second ${ }^{18} \mathrm{O}$ atom (structure 24) which, after removal of isopropylidene group, afforded the di- $O^{2}, 5^{5}\left[{ }^{18} \mathrm{O}\right]-$ labeled uridine 25 .

The nonstereoselective synthesis of $3{ }^{2}\left[{ }^{18} \mathrm{O}\right]$ uridine was reported by McCloskey, et al. using the moderately unstable 3 '-keto derivative 27 as the critical intermediate 


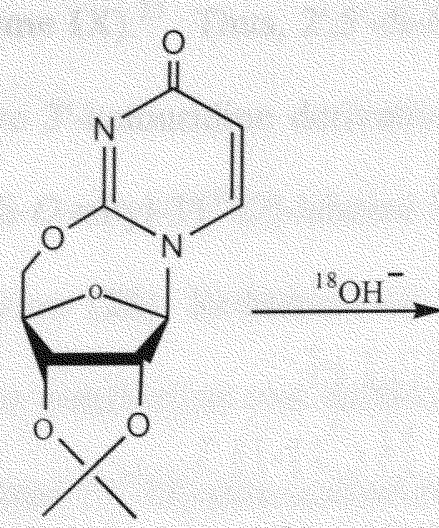

18

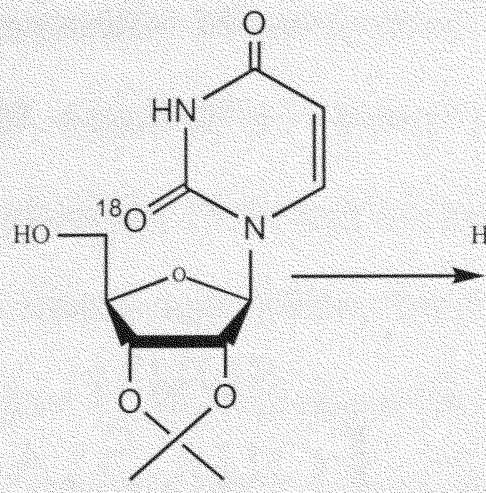

19

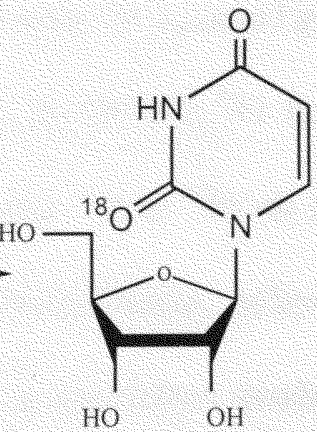

20

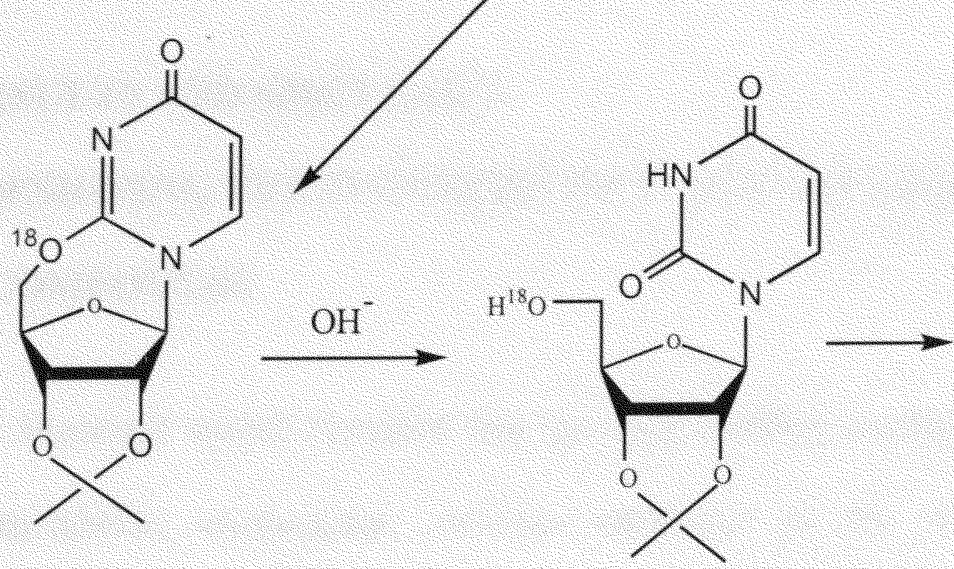

21

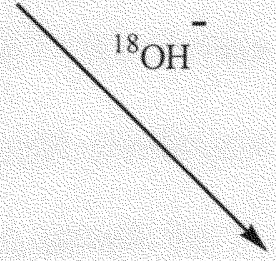

22<smiles>O=C1C=Cn2c(=O)[nH]c(=O)n2[C@H]2O[C@H]1C2O</smiles>

23<smiles>O=C1C=Cn2c(=O)[nH]c(=O)n2[C@H]2O[C@H]1C(O)[C@H]2O</smiles>

Scheme VIII: A general method for the synthesis of specifically labeled pyrimidine nucleosides by Schram, et al. $^{34}$ 
(Scheme IX). ${ }^{35}$ Thus, 2',5'-di-O-trityluridine 26 was oxidized with $\mathrm{CrO}_{3} / \mathrm{Ac}_{2} \mathrm{O} /$ pyridine to give $3^{\prime}$-ketouridine derivative 27 . Ketone 27 was treated with $\mathrm{HCl}-\mathrm{H}_{2}{ }^{18} \mathrm{O}$ to afford $2^{\prime}, 5^{\prime}$-di-O-trityl-3' $\left[{ }^{18} \mathrm{O}\right]$-labeled $3^{\prime}$-ketouridine 29 through exchange ${ }^{18} \mathrm{O}$ to ${ }^{16} \mathrm{O}$ via hydrate formation (28). Reduction of the ketone with $\mathrm{NaBH}_{4}$ and detritylation followed by tedious purification and isolation gave $3^{\prime}\left[{ }^{18} \mathrm{O}\right]$-ribo isomer 31 as the minor product and undesired $3{ }^{\prime}\left[{ }^{18} \mathrm{O}\right]$-xylo isomer $\mathbf{3 0}$ as a major product (major to minor ratio $3: 1$ ).

\section{RESULTS AND DISCUSSION}

\subsection{DESIGNING THE SYNTHESIS OF 3'-OXYGEN LABELED COMPOUNDS}

A literature search revealed that the only method available for the synthesis of 3'oxygen-labeled nucleosides involves oxidation of the 3'-OH function to 3'-keto derivatives (e.g., 27). ${ }^{35}$ The $3^{\prime}$-keto derivatives are then equilibrated with 18-oxygen labeled $\mathrm{H}_{2} \mathrm{O}$ under acidic conditions to give ${ }^{18} \mathrm{O}$-labeled 3'-ketone (e.g., 29). Subsequent reduction with $\mathrm{NaBH}_{4}$ affords the 3'-oxygen labeled nucleoside derivatives as epimers of xylo $\mathbf{3 0}$ and ribo $\mathbf{3 1}$ derivatives (Scheme IX) ${ }^{35}$

Disadvantages of such an approach include:

a) Unfavorable reduction of $3^{\prime}$-ketone which, due to steric hindrance, gives the undesired xylo epimer 30 as the major product (xylo/ribo 3:1).

b) Introduction of costly ${ }^{17} \mathrm{O}$-labeled material into the ribose moiety in the early stage of synthesis of the targeted 2'-azido-2'-deoxyuridine inhibitor. 


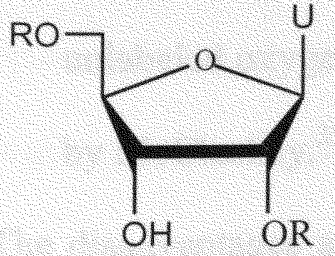

26

29

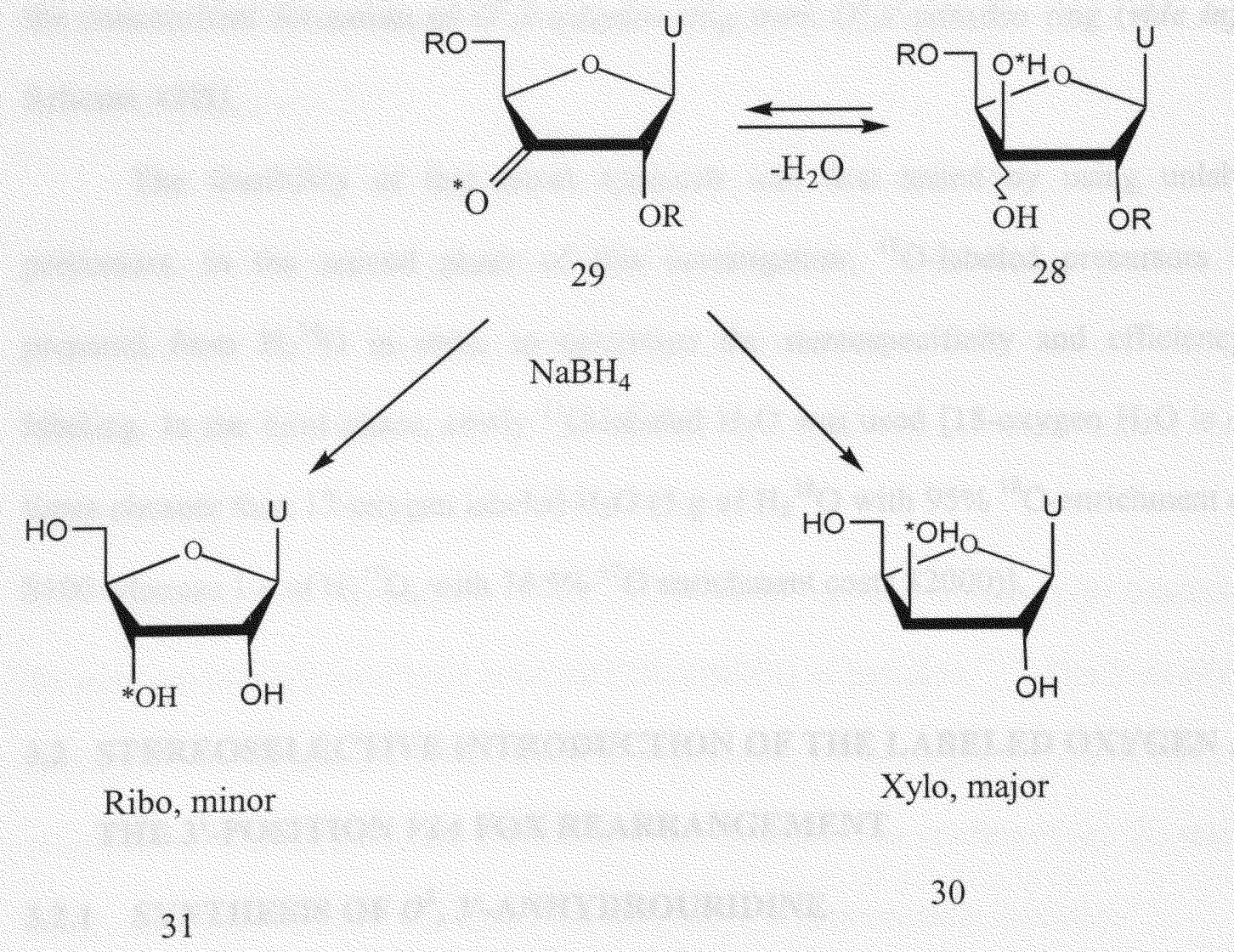

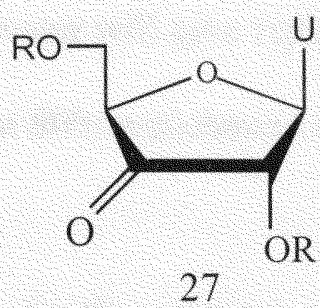

$\int_{1} \mathrm{H}_{2}{ }^{*} \mathrm{O} / \mathrm{H}^{+}$

Scheme IX: Synthesis of 3'-oxygen labeled nucleosides by McCloskey, et al. ${ }^{35}$ 
c) Equilibrium of $3^{\prime}$-ketone with ${ }^{18} \mathrm{O}$ and ${ }^{17} \mathrm{O}$ labeled water will give replacement of unlabeled oxygen by labeled oxygen only with about $80 \%$ enrichment as reported by McCloskey. ${ }^{35}$

The disadvantages associated with the ketone approach for the synthesis of oxygenlabeled nucleosides prompted us to explore new methods for the selective labeling of the sugar moiety. We designed a synthesis of $3^{\prime}-\left[{ }^{17} \mathrm{O}\right]$ labeled $2^{\prime}$-azido-2'-deoxyuridine based on the rearrangement ${ }^{36}$ of the $2^{\prime}-O$-benzoyl precursor into a $3^{\prime}$-O-benzoyl product with the concomitant formation of $O^{2}, 2$-anhydro ring from $O^{2}, 3^{\prime}$-anhydro ring (vide infra ;

\section{Scheme XIII).}

The feasibility of this novel approach was first tested by using unlabeled precursors. In the second phase of this investigation, ${ }^{18} \mathrm{O}$-labeled precursors were prepared from $\mathrm{H}_{2}{ }^{18} \mathrm{O}$ in order to determine the stereospecificity and efficiency of labeling. In the third phase, costly ${ }^{17} \mathrm{O}$-labeled $\mathrm{H}_{2} \mathrm{O}$ was used [18-oxygen $\mathrm{H}_{2} \mathrm{O}$ is $\sim 100$ times cheaper than 17-oxygen labeled $\mathrm{H}_{2} \mathrm{O}\left(5 \mathrm{~g}\right.$ of $\mathrm{H}_{2}{ }^{18} \mathrm{O}$ with $95 \%{ }^{18} \mathrm{O}$-enrichment costs $\$ 100$ whereas $1 \mathrm{~g}$ of $\mathrm{H}_{2}{ }^{17} \mathrm{O}$, with $74.5 \%{ }^{17} \mathrm{O}$ enrichment costs $\left.\$ 2000\right)$ ].

\subsection{STEREOSELECTIVE INTRODUCTION OF THE LABELED OXYGEN AT THE 3'-POSITION VIA FOX REARRANGEMENT}

\subsubsection{SYNTHESIS OF $O^{2}, 3^{\prime}$-ANHYDROURIDINE}

Treatment of uridine 32 with three equivalents of triphenylmethyl chloride $(\operatorname{TrCl})$ gave 2',5'-di-O-trityluridine 33 as the only crystalline product in $45 \%$ yield as reported by Fox. ${ }^{36}$ This reaction was repeated several times at various scales from $(2 \mathrm{~g}$ to $15 \mathrm{~g})$, and no attempts were made to increase the yield by purification of the mother liquors by 
column chromatography. Treatment of 33 with methanesulfonyl chloride $(\mathrm{MsCl})$ and pyridine gave the corresponding 3'-O-mesyl derivative 34. The structure of 34 (Scheme X) was confirmed by the appearance of singlet at $\delta 2.95$ in the ${ }^{1} \mathrm{H}-\mathrm{NMR}$ spectrum for the methyl protons of the $\mathrm{CH}_{3} \mathrm{SO}_{2}$ group.

Treatment of $\mathbf{3 4}$ with sodium benzoate and $N, N$-dimethylformamide (DMF) gave $O^{2}, 3^{\prime}$-anhydro-2',5'-di- $O$-trityluridine 35 in $43 \%$ yield. Abstraction of hydrogen from the uracil base by benzoate anion and attack at the basic $\mathrm{C} 2$-oxygen at the $3^{\prime}$ position in ribose induces the displacement of the mesyl group to give the desired $O^{2}, 3^{\prime}$-anhydro2',5'-di-O-trityluridne 35.

Removal of the trityl protecting group from $\mathbf{3 5}$ was achieved with anhydrous $\mathrm{HCl}$ followed by treatment of the resulting reaction mixture with ethanol (Scheme XI). Crystallization of the crude material from methanol gave fully-deprotected $O^{2}, 3^{\prime}-$ anhydro-1-( $\beta$-D-xylofyranosyl)uracil $36(85 \%)$ as a highly polar compound in various TLC systems. ${ }^{36}$

Regioselective protection of the 5'-OH group was accomplished by treatment of 36 with tert-butyldimethylsilyl chloride (TBDMSiCl) in pyridine. ${ }^{37,38}$ The 5 '-O-silylated analog 37 was obtained in $80 \%$ yield after purification on silica gel. Crystallization from ethanol/ethyl acetate gave fine needles, and the structure was confirmed by ${ }^{1} \mathrm{H}$ - and ${ }^{13} \mathrm{C}$ NMR, mass spectrometry and elemental analysis (see Experimental Section).

\subsubsection{SYNTHESIS OF OXYGEN LABELED BENZOYL CHLORIDE}

In order to prepare ${ }^{17} \mathrm{O}$-labeled benzoyl chloride (Scheme XII), ${ }^{17} \mathrm{O}$-labeled water ( $1 \mathrm{~g}, 74.5 \%$ enrichment) was employed. First a solution of concentrated $\mathrm{HCl} / \mathrm{H}_{2}{ }^{17} \mathrm{O}$ 
<smiles></smiles><smiles>N[C@@H]1O[C@H](CO)[C@@H](O)[C@H]1O</smiles>

a

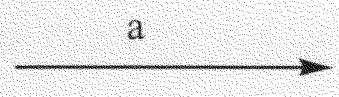
TrO-<smiles>O=C1CC=CN1</smiles>

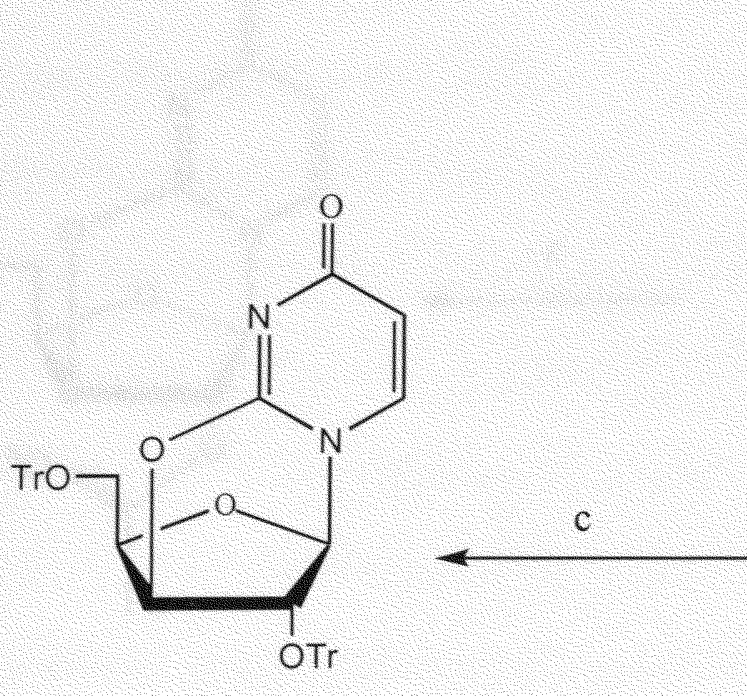

35

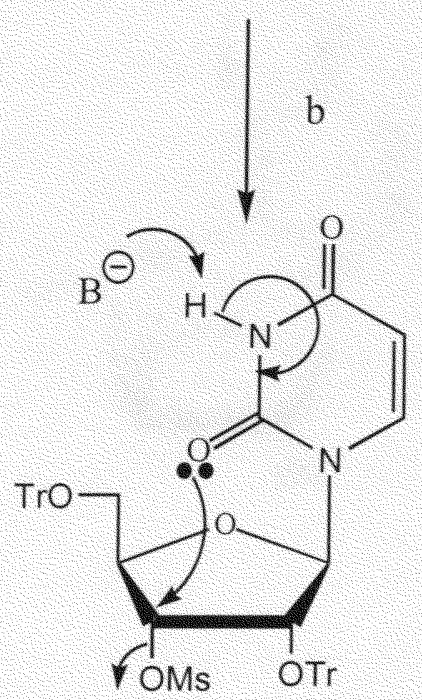

34

(a) Triphenylmethyl chloride/pyridine (b) Methanesulfonyl chloride/pyridine

(c) Sodium benzoate/DMF

Scheme X: Synthesis of $O^{2}, 3^{\prime}$-anhydrouridine 


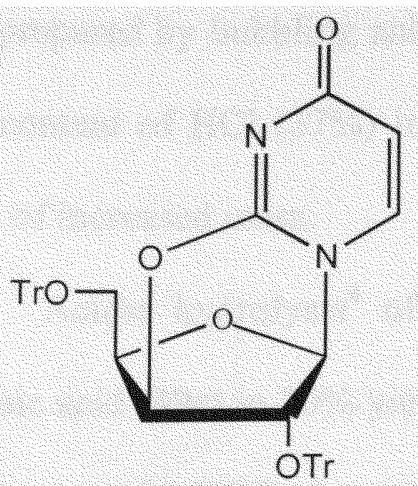

35

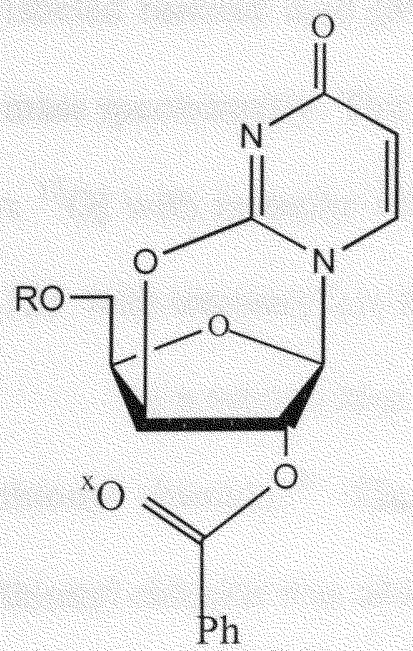

$$
\begin{aligned}
& 41 a\left(x={ }^{16} O\right) \\
& 41 b\left(x={ }^{18} O\right) \\
& 41 c\left(x={ }^{17} O\right)
\end{aligned}
$$

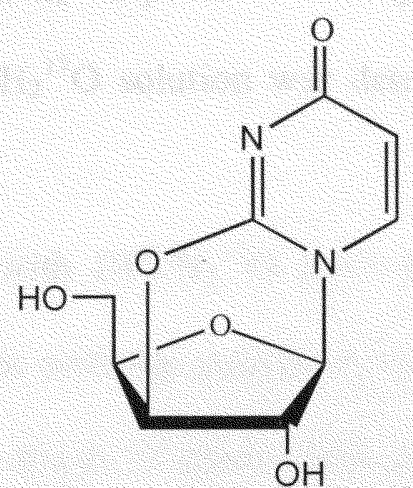

36

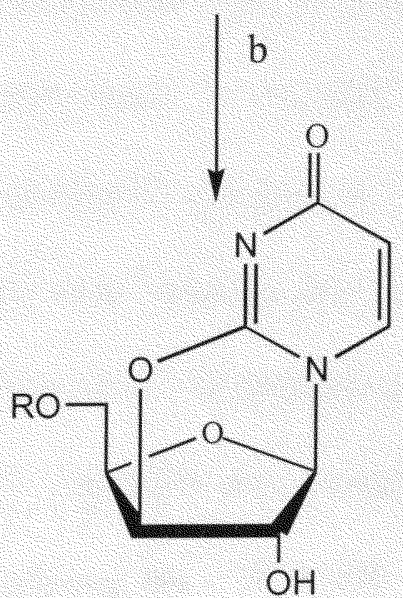

37

(a) Anhydrous $\mathrm{HCl} /$ Ethanol / Methanolic ammonia (b) Tert-butyldimethylsilyl chloride Imidazole/ DMF (c) Benzoyl chloride $\left({ }^{17} \mathrm{O} \&{ }^{18} \mathrm{O}\right)$

Scheme XI: Synthesis of 2'-O-benzoyl compounds 
was prepared by bubbling anhydrous $\mathrm{HCl}$ through $\mathrm{H}_{2}{ }^{17} \mathrm{O}$ placed in a long pressure tube.

The content of $\mathrm{HCl}(37 \%)$ in the resulting $\mathrm{HCl} / \mathrm{H}_{2}{ }^{17} \mathrm{O}$ solution was determined on the basis of increased mass.

Acidic hydrolysis ${ }^{4}$ of benzonitrile (38) with $\mathrm{HCl} / \mathrm{H}_{2}{ }^{17} \mathrm{O}$ gave the ${ }^{17} \mathrm{O}$-labeled benzoic acid (39c) in $70 \%$ yield. The crude benzoic acid was partitioned between $\mathrm{CH}_{2} \mathrm{Cl}_{2}$ and aqueous $\mathrm{NaHCO}_{3}$ in order to purify it from traces of benzonitrile and benzamide. Acidification of the aqueous layer with $\mathrm{HCl}$ and extraction with $\mathrm{CH}_{2} \mathrm{Cl}_{2}$ gave pure ${ }^{17} \mathrm{O}$ labeled benzoic acid (39c). The product was characterized by ${ }^{1} \mathrm{H}-\mathrm{NMR},{ }^{13} \mathrm{C}-\mathrm{NMR}$ and mass spectrometry. The mass spectrum showed a molecular ion peak at $\mathrm{m} / z 125\left[\mathrm{MH},{ }^{+} 2\right.$ $\mathrm{x}{ }^{17} \mathrm{O}$ ] with intensity $100 \%$, and a peak at $\mathrm{m} / \mathrm{z} 124$ with intensity $34 \%$, and peak at $\mathrm{m} / \mathrm{z}$ 123 with intensity less then $2 \%$, confirming a high level of ${ }^{17} \mathrm{O}$-incorporation.

In a second step, the $\left[{ }^{17} \mathrm{O}\right]$-labeled benzoic acid $(39 \mathrm{c})$ was treated 1.25 equiv. of thionyl chloride. ${ }^{39}$ The resulting mixture was refluxed for $1 \mathrm{~h}$ at $100{ }^{\circ} \mathrm{C}$, and excess thionyl chloride was added to keep the solution homogeneous. The reaction mixture was then distilled. Simple distillation removed excess thionyl chloride at $\sim 7 \mathrm{O}^{\circ} \mathrm{C}$ followed by benzoyl chloride $(40 \mathrm{c})$ which distilled off in one fraction. The product was colorless and had strong benzoyl chloride odor (yield $85 \%$ ).

\subsubsection{REARRRAGEMENT OF 2'-O-BENZOYL COMPOUNDS}

Treatment

$$
\text { of }
$$$$
1-\left[2,3^{\prime} \text {-anhydro-5'-O-(tert-butyldimethylsilyl)- } \beta-\mathrm{D}\right. \text { - }
$$

xylofuranosyl]uracil (37) (Scheme XI) with two equivalents of ${ }^{17} \mathrm{O}$-benzoyl chloride gave $2^{\prime}$-O-benzoyl derivative 41c. ${ }^{17} \mathrm{O}$-Labeled was incorporated at the carbonyl oxygen in $50 \%$ yield. The product was purified on a silica gel column, and unreacted starting 


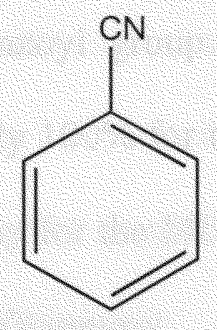

38
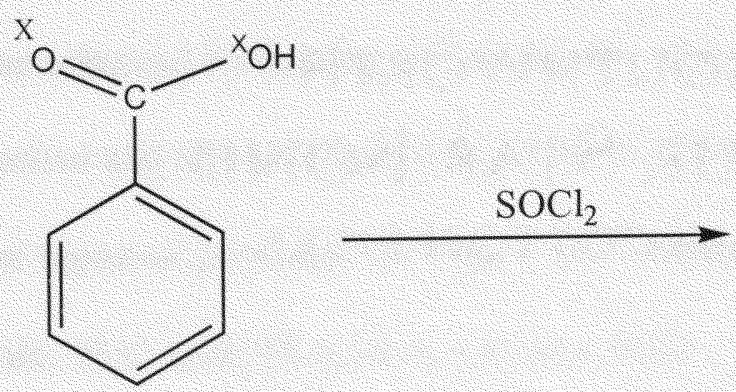

$39 a\left(x={ }^{16} O\right)$

$39 b\left(x={ }^{18} O\right)$

$39 c\left(x={ }^{17} O\right)$

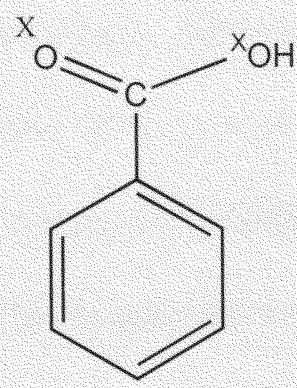

39

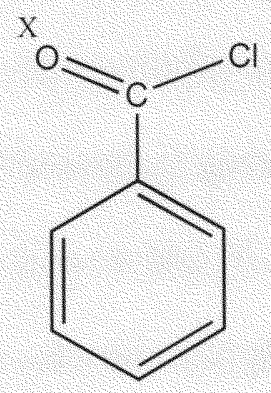

$40 \mathrm{a}\left(\mathrm{x}={ }^{16} \mathrm{O}\right)$

$40 b\left(x={ }^{18} \mathrm{o}\right)$

$40 c\left(x={ }^{17} \mathrm{O}\right)$

$$
\begin{aligned}
& X={ }^{16} O \\
& X={ }^{18} O \\
& X={ }^{17} O
\end{aligned}
$$

Scheme XII: Synthesis of oxygen labeled benzoyl chloride 
material was recovered. The product was characterized by ${ }^{1} \mathrm{H}-$ and ${ }^{13} \mathrm{C}-\mathrm{NMR}$, mass spectrometry and elemental analysis. ${ }^{1} \mathrm{H}-\mathrm{NMR}$ showed characteristic chemical shifts for the benzoyl group. Mass spectrometry showed a prominent peak at $\mathrm{m} / \mathrm{z} 446$ with intensity $100 \%$ for the ${ }^{17} \mathrm{O}$-labeled molecular ion $\left(\mathrm{MH}^{+}\right)$and a peak at $\mathrm{m} / \mathrm{z} 445$ with $77 \%$ intensity for the $\mathrm{MH}^{+}$ion of the remaining unlabeled material indicating $56 \%$ enrichment with ${ }^{17} \mathrm{O}$-isotope.

Stereospecific rearrangement of $2^{2}-O$-benzoyl compound $41 \mathrm{c}$ (with ${ }^{17} \mathrm{O}$-labeled on the carbonyl oxygen) into the $3^{\prime}$-O-benzoyl compound $42 \mathrm{c}$ (with ${ }^{17} \mathrm{O}$-labeled on $3^{\prime}$ hydroxyl directly attached to ribosyl ring) with concomitant formation of $O^{2}, 2$-anhydro ring was achieved by heating compound 41 $\mathrm{c}$ with a Bunsen burner under argon until the solid melted and turned brown (about $1 \mathrm{~min}$ ). This thermolysis method gave better results then the reported procedure of Fox, et al. ${ }^{36}$ where a sand bath at $252{ }^{\circ} \mathrm{C}$ was used for three min. TLC analysis showed that conversion was more effective and produced more reliable results than by direct heating. Controlling the flame temperature, however, is demanding and inconvenient. The product was purified on a silica gel column and was characterized by ${ }^{1} \mathrm{H}-\mathrm{NMR},{ }^{13} \mathrm{C}-\mathrm{NMR}$, mass spectrometry and elemental analysis. For example, the mass spectrum of $42 \mathrm{c}\left[{ }^{17} \mathrm{O}\right]$ showed a +1 shift for the molecular ion relative to $42 \mathrm{a}$ indicating the incorporation of one oxygen-17 atom. The ${ }^{17} \mathrm{O}$-enrichment for $42 \mathrm{c}$ was calculated to be $55 \%$ based on the relative intensities of the $\mathrm{MH}^{+}\left[{ }^{17} \mathrm{O}\right]$ and the $\mathrm{MH}^{+}\left[{ }^{16} \mathrm{O}\right]$ peaks for the corresponding isotopes. Analogously the mass spectrum of $42 \mathrm{~b}$ $\left[{ }^{18} \mathrm{O}\right]$ showed $\mathrm{a}+2$ shift of the molecular ion relative to unlabeled analog $42 \mathrm{a}$ indicating the incorporation of one oxygen-18 atom. 


\subsection{SYNTHESIS OF 2'-AZIDO- 2'-DEOXYNUCLEOTIDES}

Deprotection of the $O^{2}, 2^{\prime}$-anhydro compounds 42 was first attempted on a small scale with unlabeled analogue in order to find the best conditions for the removal of the 5'-O-silyl protecting group and the 3'-O-benzoyl group in the presence of the basesensitive $O^{2}, 2^{\prime}$-anhydro bridge. Two approaches were investigated. In the first approach, removal of the $5^{\prime}-O$-silyl protecting group with $\mathrm{NH}_{4} \mathrm{~F} / \mathrm{MeOH}^{40}$ was followed by removal of the 3'-benzoyl group with $\mathrm{NH}_{3} / \mathrm{MeOH}$. TLC showed polar, lower moving compounds in low yields. In a second approach, benzoyl protection was removed by first adding $\mathrm{NH}_{3} / \mathrm{MeOH}$ and stirring the compound for one hour. The 5'-O-silyl protecting group was then removed by adding $\mathrm{NH}_{4} \mathrm{~F} / \mathrm{MeOH}^{40}$ TLC indicated formation of a more polar product as well as stability of $O^{2}, 2$-anhydro bridge.

Labeled 5'-O-TBDMS-2'- ${ }^{17} O$-benzoyl- $O^{2}, 2^{\prime}$-anhydrouridine (42c) was dissolved in $\mathrm{MeOH} / \mathrm{NH}_{3}$ and stirred for two hours. The reaction mixture was evaporated, and the residue was treated with excess $\mathrm{NH}_{4} \mathrm{~F}$ in $\mathrm{MeOH}$ and stirred at room temperature overnight. Purification by Reverse Phase-HPLC gave product $43 \mathrm{c}$ as white crystals in $65 \%$ yield. The ${ }^{1} \mathrm{H}-\mathrm{NMR}$ and ${ }^{13} \mathrm{C}$-NMR gave identical chemical shifts for compound $43 \mathrm{c}$ as those reported in the literature for the unlabeled analog $43 \mathbf{a}^{41}$ The mass spectrum, using the APCI technique, showed a peak at $m / z 227$ with intensity $100 \%$ for $\mathrm{MH}^{+}\left[{ }^{16} \mathrm{O}\right.$ ] and a peak at $\mathrm{m} / \mathrm{z} 228$ with intensity $98 \%$ for $\mathrm{MH}^{+}\left[{ }^{17} \mathrm{O}\right.$ ] proving that ${ }^{17} \mathrm{O}$-enrichment at $\sim 50 \%$ level had occurred.

Several attempts were made to synthesize $3{ }^{3}\left[{ }^{17} \mathrm{O}\right]$-labeled 2'-azido-2'-deoxyuridine. First, the Moffatt procedure ${ }^{42}$ for the ring opening of $O^{2}, 2^{\prime}$-anhydrouridine 43a with azide anion was tested on unlabeled compound. Treatment of 43a with lithium azide and 
hexamethylphosphoramide (HMPA) followed by purification on silica gel and Dowex as described by Moffat, et al ${ }^{41}$ gave desired $44 \mathrm{a}$ in $\sim 20 \%$ yield. Cleavage of glycosylic linkage with the formation of uracil had occurred. Other attempts to improve the yield for the conversion of $43 \mathbf{a}$ into the 2 -azido-2'-deoxyuridine failed repeatedly giving poorer results than the $43 \%$ yield reported in the literature. ${ }^{42}$

In 1994 Kirschenbenter, et al. ${ }^{43}$ reported an improved synthesis of the 2'-azido-2'deoxyuridine employing generated in situ lithium azide. Treatment of 43a with LiF, $N, N, N, N$-tetramethylethylenediamine (TMEDA) and azidotrimethylsilane $\left(\mathrm{Me}_{3} \mathrm{SiN}_{3}\right)$ reagent gave $44 \mathrm{a}$ in higher yield (83\%) than the Moffatt procedure. A second approach employed $\mathrm{LiN}_{3}$ which was complexed with 18-crown-6. While both sets of conditions gave 2'-azido-2'-deoxyuridine in higher yield $(\sim 60 \%)$, difficulties in purification of the final product from the 18-crown-6 ether was experienced in the second approach.

The 3' ${ }^{17} \mathrm{O}$-labeled $\mathrm{O}^{2}, 2^{\prime}$-anhydrouridine $43 \mathrm{c}$ was added to $\mathrm{LiN}_{3}$ generated in situ from $\mathrm{LiF}$ and $\mathrm{Me}_{3} \mathrm{SiN}_{3}$. The reaction mixture was worked up with methanol and ethyl acetate. After purification on silica gel and RP-HPLC, the product $44 \mathbf{c}$ was obtained in 27 $\%$ yield (Scheme XIII). Proton NMR of $44 \mathrm{c}$ showed the identical chemical shift as reported previously in the literature for the unlabeled analog. ${ }^{42,43}$ Mass spectrometry confirmed the presence of isotopic labeling. MS using APCI technique showed a molecular ion peak at $m / z 271$ with $100 \%$ intensity for $\mathrm{MH}^{+}\left[{ }^{17} \mathrm{O}\right]$ with respect to the peak at $m / z 270$ for $\mathrm{MH}^{+}\left[{ }^{16} \mathrm{O}\right.$ ] isotope with $98 \%$ intensity, confirming $50 \%$ enrichment of 17 oxygen at 3'-hydroxyl group. 


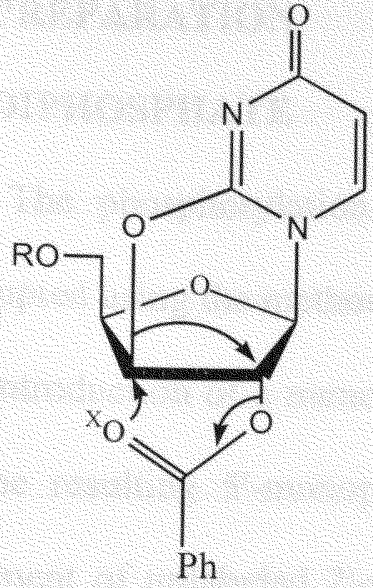

$41 \mathrm{a} / 41 \mathrm{~b} / 41 \mathrm{c}$

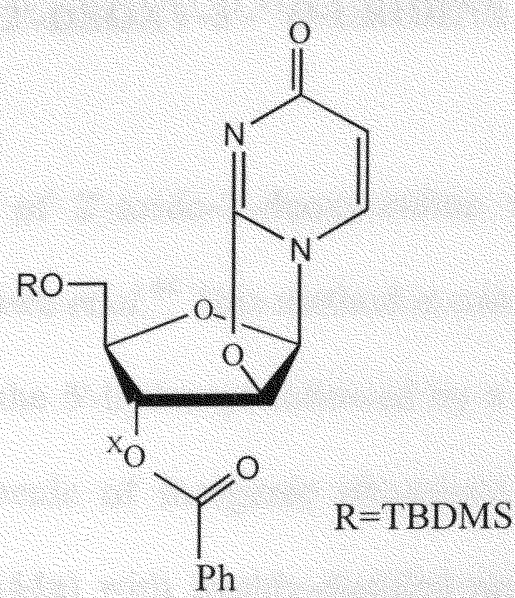

$42 a / 42 b / 42 c$

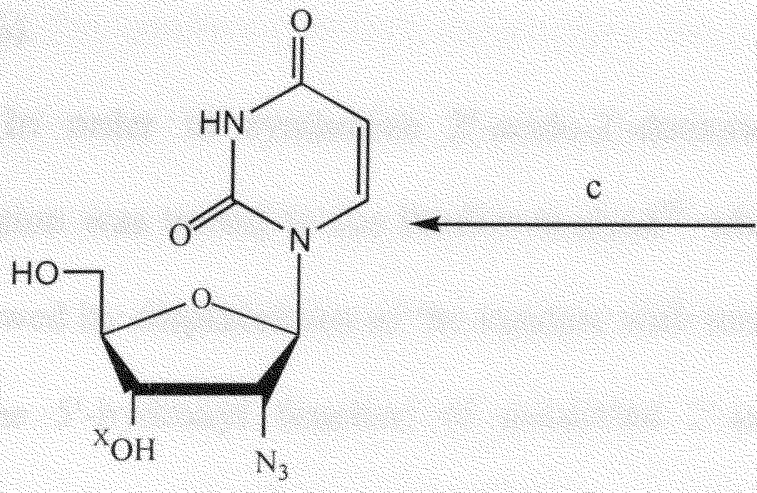

$44 a / 44 c$
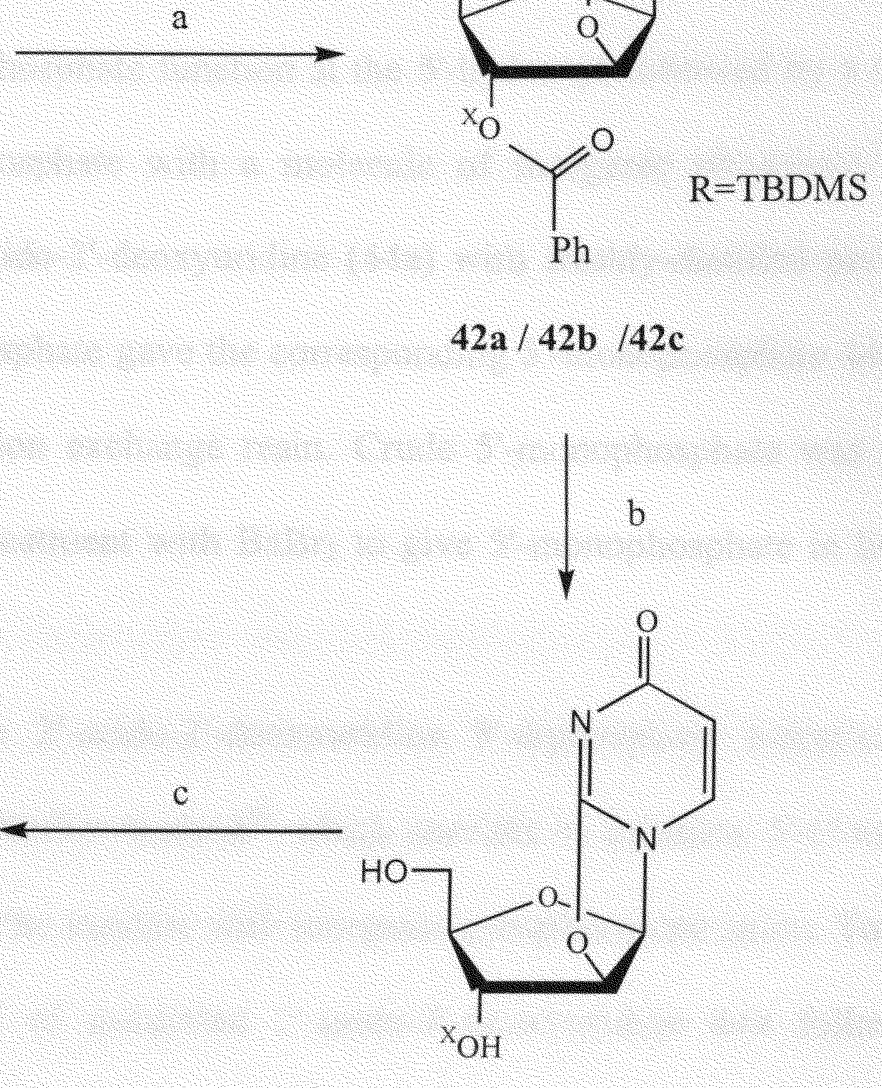

$43 a / 43 b / 43 c$

$$
\begin{array}{ll}
X={ }^{16} O & a=X\left({ }^{16} O\right) \\
X={ }^{18} O & b=X\left({ }^{18} O\right) \\
X={ }^{17} O & c=X\left({ }^{17} O\right)
\end{array}
$$

(a) $252{ }^{\circ} \mathrm{C}$ (b) Ammonia/MeOH and $\mathrm{NH}_{4} \mathrm{~F} / \mathrm{MeOH}$ (c) $\mathrm{LiF} / \mathrm{Me}_{3} \mathrm{SiN}_{3} / \mathrm{TMEDA} / \mathrm{DMF}$

Scheme XIII: Synthesis of 2'-Azido- $3^{\prime}-{ }^{17} O-2^{\prime}$-deoxyuridine 


\section{DIPHOSPHATE}

The phosphorylation of the 5'-OH group of 2'-azido-2'-deoxyuridine was first attempted using the method developed by Yoshikawa et $_{\text {al }}{ }^{44}$ This method is composed of the introduction of a monophosphate function at the 5'-hydroxyl followed by a coupling of the resulting $5^{\prime}$-monophosphate with a molecule of inorganic phosphate. ${ }^{28}$ Thus, treatment of unlabeled 2'-azido-2'-deoxyuridine (44a) with freshly-distilled phosphorus oxychloride and triethyl phosphate gave the corresponding 5'-monophosphate $44 \mathrm{a}$ which was purified on Sephadex ion exchange resin. Crude 5'-monophosphate was purified from excess phosphate by treatment with $\mathrm{BaBr}_{2}$ to give 5'-monophosphate in low yield $(15 \%)$.

In order to synthesize 2'-azido-2'-deoxyuridine 5'-diphosphate compounds 46 , attention was turned to the Poulter method ${ }^{45}$ which consists of selective 5 '-O-tosylation followed by displacement of the tosylate with inorganic pyrophosphate anion. Tosylation of the 5'-hydroxyl function of unlabeled 2'-azido-2'-deoxyuridine $44 \mathbf{a}$ followed by displacement of the 5 - $O$-tosylate from the resulting $45 \mathbf{a}$ by tris(tetra- $n$-butylammonium) hydrogen pyrophosphate gave the diphosphorylated product 46a in moderate yield $(52 \%)$.

Treatment of $3^{\prime}\left[{ }^{17} \mathrm{O}\right]$-labeled $2^{\prime}$-azido-2'-deoxyuridine $(\mathbf{4 4 c})(16 \mathrm{mg})$ with 1.5 equivalents of tosyl chloride in pyridine gave a mixture of $5^{\prime}$ - $O$-monotosyl product $45 \mathrm{c}$ along with small quantities of the corresponding 3',5'-di-O-tosyluridine byproduct. The 5'-monotosylated compound $\mathbf{4 5} \mathbf{c}$ was separated from ditosylated compound on a silica gel column. The product $45 \mathrm{c}$ was obtained in $63 \%$ yield and was characterized by ${ }^{1} \mathrm{H}$ - and 
${ }^{13} \mathrm{C}-\mathrm{NMR}$ and mass spectrometry. Mass spectrometry showed $\sim 50 \%$ of ${ }^{17} \mathrm{O}$-enrichment based on the ${ }^{17} \mathrm{O} /{ }^{16} \mathrm{O}$ isotope distribution.

In order to synthesize the final compound, 3 '[ $\left.{ }^{17} \mathrm{O}\right]$-labeled 2 '-azido-2'-deoxyuridine 5'-diphosphate (46c) (Scheme XIV), tosylate 45c was treated with 1.5 equivalents of tris(tetra- $n$-butylammonium) hydrogen pyrophosphate in acetonitrile for 24 hour at ambient temperature. The reaction mixture was evaporated to remove acetonitrile, and the crude $46 \mathrm{c}$ was diluted with water and purified on a Sephadex ion exchange column using triethylammonium bicarbonate as a gradient eluant. Proton NMR showed the presence of triethylammonium salt in the product. The product was converted to its sodium salt by passing it through a Dowex $\left(\mathrm{Na}^{+}\right)$column that was prepared from Dowex $\left(\mathrm{H}^{+}\right)$. The product obtained, diphosphate $46 \mathrm{c}$, was characterized by ${ }^{1} \mathrm{H}-\mathrm{NMR}$ and ${ }^{31} \mathrm{P}-$ NMR. Proton NMR showed no peaks for the TEA salt. Phosphorus-31 NMR showed that compound $46 \mathrm{c}$ still contained $70 \%$ inorganic pyrophosphate as impurity.

The final purification of compound 46c was achieved on RP-HPLC with a semipreparative column (Supelcosil LC-18T). Elution with $3 \% \mathrm{H}_{2} \mathrm{O} / \mathrm{CH}_{3} \mathrm{CN}$ gave the ${ }^{17} \mathrm{O}$ labeled diphosphate $46 \mathrm{c}(4 \mathrm{mg}, 22 \%)$ with a retention time of 5-6 minutes. The compound was characterized by ${ }^{1} \mathrm{H}-\mathrm{NMR}$ and ${ }^{31} \mathrm{P}-\mathrm{NMR}$. Phosphorus-31 NMR showed that the compound contained $50 \%$ of the inorganic pyrophosphate as an impurity and also consist of two doublets of doublets at $\delta-10.17$ and $\delta-9.26$ for phosphorus $\alpha$ and $\beta$ with a coupling constant of $J p_{\alpha} \cdot p_{\beta}=21.2 \mathrm{~Hz}$ diagnostic for diphosphate $46 \mathrm{c}$.

Biological studies with the $3^{\prime}\left[{ }^{17} \mathrm{O}\right]-2$ '-azido-2'-deoxyuridine 5 '-diphosphate $46 \mathrm{c}$ are now being performed in Professor Stubbe's laboratory at the Massachusetts Institute of Technology. Enzymatic studies with ribonucleoside diphosphate reductase (RDPR) 


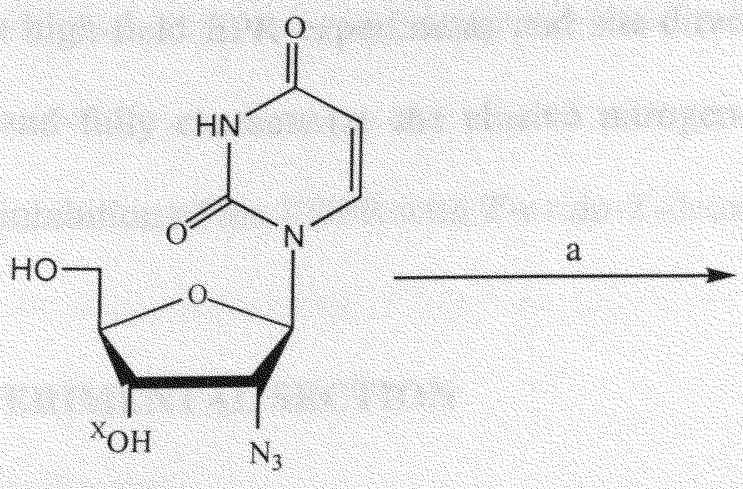

$44 a / 44 c$

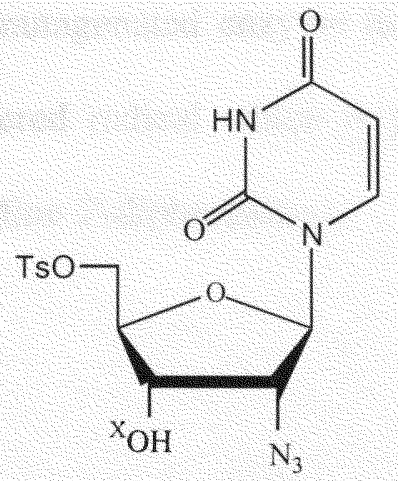

$45 a / 45 c$

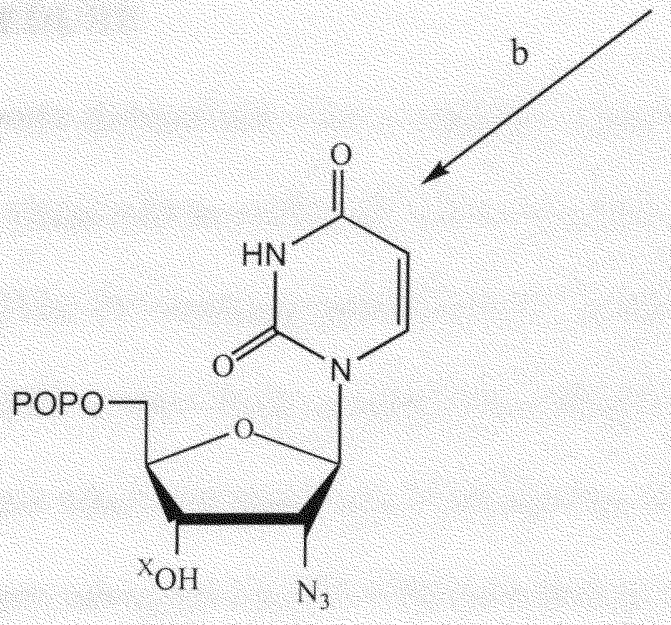

$46 a / 46 c$

$$
\begin{array}{ll}
X={ }^{16} O & a=X\left({ }^{16} O\right) \\
X={ }^{18} O & b=X\left({ }^{18} O\right) \\
X={ }^{17} O & c=X\left({ }^{17} O\right)
\end{array}
$$

(a) Toluene sulfonyl chloride/pyridine (b) Tris(tetra- $n$-butylammonium) hydrogen pyrophosphate

Scheme XIV: Preparation of 2'-azido-2'-deoxy-3'- ${ }^{17} O$-uridine 5'-diphosphate 
involve high-field EPR experiments and site-directed mutagenated enzyme in order to detect and fully characterize the elusive nitrogen-centered radical which is generated during inhibition of the RDPR with 2'-azido-2'-deoxyuridine 5'-diphosphates.

\section{EXPERIMENTAL SECTION}

\subsection{GENERAL PROCEDURE}

Melting points were determined with a capillary apparatus and are uncorrected. Ultraviolet spectra were measured in methanol, absolute ethanol, $50 \%$ ethanol and water using a Shimadzu UV-2101 PC scanning spectrometer. ${ }^{1} \mathrm{H}-(400 \mathrm{MHz}),{ }^{13} \mathrm{C}-(100 \mathrm{MHz})$ and ${ }^{31} \mathrm{P}-(161.7 \mathrm{MHz})$ NMR spectra were recorded on a Bruker NMR spectrometer with solutions in $\mathrm{CDCl}_{3}$, unless otherwise specified. Mass spectra were obtained by chemical ionization using a Finnigan navigator LC/MS with methanol as the solvent. Evaporations were effected with a Büchi rotary evaporator under water aspirator or mechanical oil pump at $<35^{\circ} \mathrm{C}$. Preparative Reverse-Phase (RP)-HPLC was performed on a Supelcosil LC-18S column utilizing a Perkin-Elmer LC 200 binary pump system (gradient solvent systems are noted). Elemental analyses were determined by Galbraith Laboratories, Knoxville, TN. Merck kiselgel $60-\mathrm{F}_{254}$ sheets were used for TLC, and products were detected under $254 \mathrm{~nm}$ light. Merck Kieselgel 60 (230-400 mesh) was used for column chromatography. Unless otherwise specified, solvents used for column chromatography and TLC were as follows: (S1) EtOAc; (S2) SSE [the upper phase of EtOAc/i-PrOH/ $\mathrm{H}_{2} \mathrm{O}$ (4:1:2)]; (S3) EtOAc/SSE (90:10); (S4) EtOAc/SSE (75:25); (S5) DSSE (30\% MeOH in SSE); (S6) $\mathrm{CHCl}_{3} / \mathrm{MeOH}$ (95:5); (S7) $i$ - $\mathrm{PrOH} / \mathrm{NH}_{4} \mathrm{OH} / \mathrm{H}_{2} \mathrm{O}$ (3:1:1). Reagent grade 
chemicals were used, and solvents were dried by reflux over and distillation from calcium hydride under argon. Sonication was performed with a Branson 5200 ultrasonic bath. Ion exchange chromatography was performed with Sephadex-DEAE A-25, (40-120 $\mu)$ and Dowex-50W-hydrogen foam, $2 \%$ cross linking, 100-200 mesh ion exchange resin.

\subsection{SYNTHESIS}

\section{2 ',5'-Di-O-trityluridine (33)}

Uridine (32) (11 g, $45 \mathrm{mmol})$, dissolved in anhydrous pyridine $(95 \mathrm{~mL})$, was treated with three equivalents of triphenylmethyl chloride $(36 \mathrm{~g}, 129 \mathrm{mmol})$ and allowed to remain at room temperature overnight. The resulting red solution was heated at 110 ${ }^{\circ} \mathrm{C}$ for four hours after which it was cooled, poured into water, and stirred. After decantation, the gummy solid was again treated with water, stirred and the water decanted. This process was repeated several times after which the residue was dissolved in acetone and concentrated to dryness. The resulting viscous liquid was treated with 500 $\mathrm{mL}$ of hot water, stirred, and the water decanted. This process was repeated twice. The residue was dissolved in methylene chloride and dried over anhydrous sodium sulphate. After filtration, the solution was concentrated and treated with a minimum amount of hot benzene to give a homogeneous solution. Diethyl ether was added to the point of faint opalescence. After cooling (and scratching), a creamy solid precipitated that was filtered to give $33(32 \mathrm{~g}, 45 \%)$ : $\mathrm{mp} 224-225^{\circ} \mathrm{C}$ (lit. ${ }^{46} \mathrm{mp} 223-224{ }^{\circ} \mathrm{C}$ ); UV $\max 264 \mathrm{~nm}$, min 245 nm; 'H NMR $\delta 2.30$ (br s, 1, OH3'), 2.80 (d, $\left.J_{3^{\prime}-2^{\prime}}=4.6 \mathrm{~Hz}, 1, \mathrm{H} 3^{\prime}\right) 3.12$ (br s, 2, H5',5"), $3.98\left(\right.$ br s, $\left.1, H 4^{\prime}\right), 4.51\left(\mathrm{t}, J_{2^{\prime}-1^{\prime}}=4.7 \mathrm{~Hz}, 1, \mathrm{H} 2^{\prime}\right), 5.11\left(\mathrm{~d}, J_{1^{\prime}-2^{\prime}}=6.1 \mathrm{~Hz}, 1, \mathrm{H} 1^{\prime}\right), 6.36(\mathrm{~d}$, 
$\left.J_{5-6}=7.4 \mathrm{~Hz}, 1, \mathrm{H} 5\right), 7.00-7.60\left(\mathrm{~m}, 15, \mathrm{H}_{\text {arom }}\right), 7.70\left(\mathrm{~d}, J_{6-5}=8.0 \mathrm{~Hz}, 1, \mathrm{H} 6\right), 8.50(\mathrm{~s}, 1$, NH).

\section{3'-O-Methanesulfonyl-2'-5'-di- $O$-trityluridine (34)}

Methanesulfonyl chloride $(1.1 \mathrm{~mL})$ was added dropwise to a cooled solution of $\mathbf{3 3}$ $(8.8 \mathrm{~g}, 12 \mathrm{mmol})$ in anhydrous pyridine $(100 \mathrm{~mL})$, and the reaction mixture was stored at $\sim 5^{\circ} \mathrm{C}$ for $16 \mathrm{~h}$. A crystalline product was formed during this time. The reaction mixture was treated with ethanol $(2 \mathrm{~mL})$ and allowed to stand for $2 \mathrm{~h}$ more. After concentration in vacuo to a red syrup, the residue was treated with ethanol $(200 \mathrm{~mL})$ whereupon a heavy white precipitate formed. After filtration and trituration of the precipitate with ethanol, a solid was obtained $(7.3 \mathrm{~g}, 75 \%)$ which was washed repeatedly with ethanol and diethyl ether and was dried under vacuum. This crude product was recrystallized from ethanol to

afford pure 34: $\mathrm{mp} 224-226^{\circ} \mathrm{C}$ (lit. ${ }^{36} \mathrm{mp} 225-226^{\circ} \mathrm{C}$ ); UV $\max 259 \mathrm{~nm}$, $\min 242 \mathrm{~nm} ;{ }^{\prime} \mathrm{H}$ NMR $\delta 2.95$ (s, 3, Me), 3.25 (“dd", $\left.J_{5^{\prime}-5^{\prime \prime}}=10.8 \mathrm{~Hz}, 2, \mathrm{H} 5^{\prime}, 5^{\prime \prime}\right), 4.25\left(\mathrm{~d}, J_{3^{\prime}-2^{\prime}}=5.0 \mathrm{~Hz}, 1\right.$, H3'), 4.42 (br s 1, H4'), 4.66 (t, $J=7.6 \mathrm{~Hz}, 1, \mathrm{H} 2$ '), 5.14 (d, $J_{5-6}=8.1 \mathrm{~Hz}, 1, \mathrm{H} 5$ ), 6.99 (d, $\left.J_{1^{\prime}-2^{\prime}}=7.8 \mathrm{~Hz}, 1, \mathrm{H} 1^{\prime}\right), 6.96\left(\mathrm{~d}, J_{6-5}=7.4 \mathrm{~Hz}, 1, \mathrm{H} 6\right), 7.00-7.80\left(\mathrm{~m}, 15, \mathrm{H}_{\text {arom }}\right), 8.80(\mathrm{~s}, 1$, $\mathrm{NH})$.

\section{1-(2, 3'-Anhydro -2', 5'-di- $O$-trityl- $\beta$-D-xylofuranosyl)uracil (35)}

Compound $34(7.0 \mathrm{~g}, 8.7 \mathrm{mmol})$ was added to a suspension of sodium benzoate $(14 \mathrm{~g})$ in DMF $(280 \mathrm{~mL})$ and heated at $130-140^{\circ} \mathrm{C}$ (internal temperature) for $18 \mathrm{~h}$. The cooled mixture was treated with $1 \mathrm{~L}$ of water and stirred for $2 \mathrm{~h}$. The precipitate was separated and washed well with water. After filtration, the precipitate was triturated with 
ethanol $(100 \mathrm{~mL})$ whereupon a white granular precipitate slowly formed. After $2 \mathrm{~h}$ of stirring, the precipitate was filtered from the amber colored solution. The precipitate was directly chromatographed on a silica gel column. Gradient elution $(80 \%$ EtOAc/hexane $\rightarrow$ EtOAc $\rightarrow 5 \% \mathrm{MeOH} /$ EtOAc) and evaporation of the appropriate fractions $\left(\mathrm{R}_{\mathrm{f}}\right.$ in $\mathrm{S} 1$ 0.8) gave 35 (2.6 g, 43\%); mp 237-238 ${ }^{\circ} \mathrm{C}$ (lit. ${ }^{36} 237^{\circ} \mathrm{C}$ ); UV max 248,269 (shoulder) $\mathrm{nm}, \min 239 \mathrm{~nm} ;{ }^{1} \mathrm{H}$ NMR $\delta 3.29\left(\mathrm{dd}, J_{5^{\prime}-5^{\prime \prime}}=9.7 \mathrm{~Hz}, J_{5^{\prime}-4^{\prime \prime}}=3.2 \mathrm{~Hz}, 1, \mathrm{H} 5^{\prime \prime}\right), 3.34\left(\mathrm{dd}, J_{5^{\prime}-}\right.$ $\left.4^{\prime \prime}=4.2 \mathrm{~Hz}, \mathrm{H} 5^{\prime}\right), 4.03\left(\mathrm{q}, J_{4^{\prime}-3^{\prime}}=6.8 \mathrm{~Hz}, 1, \mathrm{H} 4^{\prime}\right), 4.41$ (“"s", 1, H3'), 4.53 (““dt”, $J_{2^{\prime}-3^{\prime}}=2.1$ $\left.\mathrm{Hz}, 1, \mathrm{H} 2^{\prime}\right), 4.59$ (s, 1, H1'), $5.76\left(\mathrm{~d}, J_{5-6}=7.4 \mathrm{~Hz}, 1, \mathrm{H} 5\right), 6.28$ (d, $\left.J_{6-5}=7.4 \mathrm{~Hz}, 1, \mathrm{H} 6\right)$, 7.00-7.50 (m, 15, $\left.\mathrm{H}_{\text {arom }}\right)$.

\section{1-(2, 3'-Anhydro- $\beta$-D-xylofuranosyl)uracil (36)}

Compound $35(2.2 \mathrm{~g}, 3.0 \mathrm{mmol})$ was placed in ethanol $(50 \mathrm{~mL})$ which had been saturated with anhydrous hydrogen chloride $\left(0{ }^{\circ} \mathrm{C}\right.$ for 10 minutes $)$, and kept $\sim 70{ }^{\circ} \mathrm{C}$ for 10 miniuets. The solution was concentrated in vacuo to a syrup and repeatedly evaporated with benzene. Absolute ethanol $(10 \mathrm{~mL})$ was added to the syrup and cooled to $0{ }^{\circ} \mathrm{C}$. The resulting solution was neutralized to about $\mathrm{pH} 5$ with methanolic ammonia whereupon crystallization took place. Recrystallization from $95 \%$ methanol gave pure 36 (0.6 g, 85\%); mp. 227-228 ${ }^{\circ} \mathrm{C}$ (lit. $\left.{ }^{36} \mathrm{mp} 225-227\right)$; UV $\max 231 \mathrm{~nm}, \min 215 \mathrm{~nm} ;{ }^{1} \mathrm{H}$ $\operatorname{NMR}\left(\mathrm{D}_{2} \mathrm{O}\right) \delta 3.61$ (m, 2, H5', 5"), 4.45 (s, 1, H4'), 4.70 (br s, 1, H3'), 4.97 (s, 1, H2'), 5.55 (br s, 1, H1'), 5.91 (d, $\left.J_{5-6}=7.3 \mathrm{~Hz}, 1, \mathrm{H} 5\right), 7.55$ (d, $J_{6-5}=7.4 \mathrm{~Hz}, 1, \mathrm{H} 6$ ). 


\section{1-[2, 3'-Anhydro-5'-O-(tert-butyldimethylsilyl)- $\beta-\mathrm{D}-\mathrm{xyl}$ - $3^{\prime}$ furanosyl]uracil (37)}

To a suspension of 1-(2,3'-anhydro- $\beta$-D-xylofuranosyl)uracil (36) (1.13 g, 5 $\mathrm{mmol})$ in anhydrous DMF $(30 \mathrm{~mL})$ were added imidazole $(0.725 \mathrm{~g}, 12.5 \mathrm{mmol})$ and tertbutyldimethylsilyl chloride $(0.903 \mathrm{~g}, 6.0 \mathrm{mmol})$. The reaction mixture was stirred overnight under argon at ambient temperature. Volatiles were evaporated under vacuum, and the residue was directly chromatographed on a silica gel column. Gradient elution $[$ EtOAc $\rightarrow 50 \% \mathrm{~S} 2 /$ EtOAc $\rightarrow \mathrm{MeOH} / \mathrm{S} 2 /$ EtOAc $(2: 49: 49)]$ and evaporation of the appropriate fractions $\left(R_{f} 0.71\right.$ in $S 3$; compound 36 had $\left.R_{f} 0.1\right)$ gave $37(1.36 \mathrm{~g}, 80 \%)$. Crystallization from EtOH/EtOAc gave sharp needles: mp $246-247^{\circ} \mathrm{C}$; UV $\max 231 \mathrm{~nm}$ ( $\varepsilon 9800), \min 216 \mathrm{~nm}(\varepsilon 6900) ;{ }^{\prime} \mathrm{H}$ NMR (DMSO- $\left.d_{6}\right) \delta 0.02(\mathrm{~s}, 6,2 \times \mathrm{Me}), 0.85(\mathrm{~s}, 9, t$ $\mathrm{Bu}), 3.71\left(\mathrm{dd}, J_{5^{\prime \prime}-5^{\prime}}=11.0 \mathrm{~Hz}, J_{5^{\prime \prime}-4^{\prime}}=6.4 \mathrm{~Hz}, 1, \mathrm{H} 5^{\prime \prime}\right), 3.81\left(\mathrm{dd}, J_{5^{\prime}-4^{\prime}}=6.0 \mathrm{~Hz}, 1, \mathrm{H} 5^{\prime}\right)$, 4.41 (“dt”, $\left.J_{4-5}, 5^{\prime \prime}=6.2 \mathrm{~Hz}, J_{4^{\prime}-3^{\prime}}=2.5 \mathrm{~Hz}, 1, \mathrm{H} 4^{\prime}\right), 4.74$ (br s, 1, H3'), 4.92 (br s, 1, H2'), $5.64\left(\mathrm{~s}, 1, \mathrm{H} 1^{\prime}\right), 5.80$ (d, $\left.J_{5-6}=7.4 \mathrm{~Hz}, 1, \mathrm{H} 5\right), 6.45$ (br s, $\left.1, \mathrm{OH} 2^{\prime}\right), 7.68(\mathrm{~d}, 1, \mathrm{H} 6) ;{ }^{13} \mathrm{C}$ NMR (DMSO- $\left.d_{6}\right) \delta-5.00(2 \times \mathrm{Me}), 18.27(t-\mathrm{Bu}), 25.99(t-\mathrm{Bu}), 61.37\left(\mathrm{C} 5^{\prime}\right), 69.73\left(\mathrm{C} 3^{\prime}\right)$, $79.47\left(\mathrm{C} 2{ }^{\prime}\right), 83.58$ (C4'), $89.64\left(\mathrm{C} 1^{\prime}\right), 108.19$ (C5), 141.33 (C6), 153.67 (C2), 170.59 ( C4); MS (CI) m/z $341\left(100, \mathrm{MH}^{+}\right), 283\left(30, \mathrm{M}^{+}-t\right.$-Bu); HRMS (CI) calcd. for $\mathrm{C}_{15} \mathrm{H}_{24} \mathrm{~N}_{2} \mathrm{O}_{5} \mathrm{Si}+\mathrm{H}$. 341.1532. Found 341.1538. Anal. Calcd. for $\mathrm{C}_{15} \mathrm{H}_{24} \mathrm{~N}_{2} \mathrm{O}_{5} \mathrm{Si}$ (340.45): C, 52.92; H, 7.11; N, 8.23. Found: C, 52.43; H, 7.26; N, 8.11.

\section{Preparation of Concentrated $\mathrm{HCl}$ in ${ }^{18} \mathrm{O}$-Labeled $\mathrm{H}_{2} \mathrm{O}$}

The Oxygen-18-labeled water $\left(1.05 \mathrm{~g}, 52.5 \mathrm{mmol} ; 97.4\right.$ atom $\%{ }^{18} \mathrm{O}$ from Isotec, Inc.) was placed in long pressure tube (Ace glass) and was cooled in an ice bath. 
Anhydrous hydrogen chloride was bubbled in for $3 \mathrm{~min}$, and the content of $\mathrm{HCl}(37 \%)$ was calculated on the basis of increased mass.

\section{Preparation of ${ }^{18} \mathrm{O}$-Labeled Benzoic Acid from Benzonitrile and $\mathrm{HCl} / \mathrm{H}_{2}{ }^{18} \mathrm{O}$} $(39 b)$

Benzonitrile (38) $(1.78 \mathrm{ml}, 1.8 \mathrm{~g}, 17.5 \mathrm{mmol})$ was suspended in concentrated $\mathrm{HCl} / \mathrm{H}_{2}{ }^{18} \mathrm{O}$ (prepared as above) in a long pressure tube, and the reaction mixture was heated for $20 \mathrm{~h}$ at $100{ }^{\circ} \mathrm{C}$ with vigorous stirring. During that time the whole reaction mixture solidified. The reaction mixture was then partitioned between cold methylene chloride and ice-cold, saturated aqueous $\mathrm{NaHCO}_{3}$ solution. The methylene chloride layer was then quickly extracted again with $\mathrm{NaHCO}_{3}$ solution. The aqueous extracts were combined and water layer was extracted back with $\mathrm{CH}_{2} \mathrm{Cl}_{2}$ to remove traces of benzonitrile and benzamides. Fresh methylene chloride was then added to the water layer, and the mixture was acidified to $\mathrm{pH} \sim 3$. The aqueous layer was separated, and the $\mathrm{CH}_{2} \mathrm{Cl}_{2}$ layer was extracted with brine. The methylene chloride layer was then dried (anhydrous $\mathrm{Na}_{2} \mathrm{SO}_{4}$ ) and evaporated to give $39 \mathrm{~b}\left(1.55 \mathrm{~g}, 70 \%\right.$ ) as a white solid. ${ }^{1} \mathrm{H}$ NMR $\delta 7.49(\mathrm{t}, J=7.4 \mathrm{~Hz}, 2, \mathrm{H}), 7.65(\mathrm{t}, J=7.4 \mathrm{~Hz}, 1, \mathrm{H}), 8.15(\mathrm{~d}, J=7.0 \mathrm{~Hz}, 2, \mathrm{H}), 13.00(\mathrm{~s}$, 1, COOH); ${ }^{13} \mathrm{C}$ NMR $\delta 128.99$ (C3), 129.81 (C1), 130.72 (C2), 134.34 (C4) 173.05 (COOH); MS (CI) m/z $127\left(100, \mathrm{MH}^{+}\left[2 \times{ }^{18} \mathrm{O}\right]\right), 126(60) 125(20), 124$ (19), 107 (65, $\left.\mathrm{PhC}^{18} \mathrm{O}^{+}\right), 105\left(2, \mathrm{PhCO}^{+}\right)$and no peaks at $\mathrm{m} / z 122$ and 123 were observed for unlabeled benzoic acid. 


\section{Preparation of Concentrated $\mathrm{HCl}$ in ${ }^{17} \mathrm{O}$-Labeled $\mathrm{H}_{2} \mathrm{O}$}

Oxygen-17 labeled water ( $1.08 \mathrm{~g}, 57.7 \mathrm{mmol} ; 74.5$ atom $\%{ }^{17} \mathrm{O}$ from Isotec, Inc.) was placed in a long pressure tube (Ace glass) and was cooled in an ice bath. Anhydrous hydrogen chloride was bubbled in for $3 \mathrm{~min}$, and the content of $\mathrm{HCl}(35.2 \%)$ was calculated on the basis of increased mass.

\section{Preparation of ${ }^{17} \mathrm{O}$ - Labeled Benzoic Acid from Benzonitrile and $\mathrm{HCl} / \mathrm{H}_{2}{ }^{17} \mathrm{O}$} $(39 c)$

Treatment of benzonitrile (38) $(2.08 \mathrm{~g}, 2.06 \mathrm{ml}, 20.2 \mathrm{mmol})$ with $\mathrm{HCl} / \mathrm{H}_{2}{ }^{17} \mathrm{O}$ (prepared as above) was effected as described for $39 \mathrm{~b}$ and afforded gave ${ }^{17} \mathrm{O}$-labeled benzoic acid 39c $(1.54 \mathrm{~g}, 62 \%)$. MS (CI) $\mathrm{m} / \mathrm{z} 125\left(100, \mathrm{MH}^{+}\left[2 \times{ }^{17} \mathrm{O}\right]\right), 124(34$, $\left.\mathrm{MH}^{+}\left[{ }^{17 / 16} \mathrm{O}\right]\right), 123\left(21, \mathrm{MH}^{+}\left[2 \mathrm{x}^{16} \mathrm{O}\right]\right)$.

\section{Preparation of ${ }^{18} \mathrm{O}$-Labeled Benzoyl Chloride (40b)}

${ }^{18} \mathrm{O}$-Labeled benzoic acid (39b) $(0.88 \mathrm{~g}, 6.98 \mathrm{mmol})$ was placed in a $25 \mathrm{~mL}$ round-bottomed flask, and thionyl chloride $(0.65 \mathrm{~mL}, 1.05 \mathrm{~g}, 8.8 \mathrm{mmol})$ was added. The reaction mixture was gently heated for $1 \mathrm{~h}$ at $100{ }^{\circ} \mathrm{C}$ (an additional $1 \mathrm{~mL}$ of thionyl chloride was added after 20 min. to minimize the effect of loss of thionyl chloride during heating and to keep the solution homogeneous). The reaction mixture was cooled after one hour and distilled. Simple distillation at atmosphere pressure removed excess $\mathrm{SOCl}_{2}$ $\left(\sim 70^{\circ} \mathrm{C}\right)$. Vacuum was then applied, and the temperature was increased to $\sim 130^{\circ} \mathrm{C}$ to distill most of the liquid in one fraction to give $40 \mathrm{~b}(0.85 \mathrm{~g}, 85 \%)$. The distilled liquid was colorless and had strong odor of benzoyl chloride. 


\section{Preparation of ${ }^{17} \mathrm{O}$-Labeled Benzoyl Chloride (40c)}

Treatment of the ${ }^{17} \mathrm{O}$-labeled benzoic acid (39c) $(1.4 \mathrm{~g}, 11.29 \mathrm{mmol})$ with thionyl

chloride $(1.67 \mathrm{~g}, 14.11 \mathrm{mmol})$ as described for $40 \mathrm{~b}$ gave $\left[{ }^{17} \mathrm{O}\right]$ benzoyl chloride $(40 \mathrm{c})(1.3$ g, $80 \%)$.

\section{$1-\left[2,3^{\prime}\right.$-Anhydro-2'-O-benzoyl-5'- $O$-(tert-butyldimethylsilyl)- $\beta$-D-xylofuranosyl]}

\section{uracil (41a)}

To a solution of $37(20 \mathrm{mg}, 0.05 \mathrm{mmol})$ in anhydrous pyridine $(1 \mathrm{~mL})$ was added benzoyl chloride $(0.05 \mathrm{~mL})$, and stirring was continued overnight at ambient temperature and then for $2 \mathrm{~h}$ at $40^{\circ} \mathrm{C}$. Volatiles were removed in vacuo, and the residue was coevaporated with toluene. The crude product was chromatographed on a silica gel column. Gradient elution [EtOAc/hexane $\quad(90: 10) \rightarrow$ EtOAc $\quad \rightarrow \quad 5 \% \quad$ S2/EtOAc $\rightarrow$ $\mathrm{MeOH} / \mathrm{S} 2 /$ EtOAc $(2: 10: 88)]$ and evaporation of the appropriate fractions $\left(\mathrm{R}_{\mathrm{f}} 0.64\right.$ in $\mathrm{S} 3$; compound 37 had $R_{f} 0.12$ ) gave compound 41 a (10 mg, 50\%) as a white solid: mp 238$240{ }^{\circ} \mathrm{C}$; UV $\max 233 \mathrm{~nm}(\varepsilon 26100), \min 213 \mathrm{~nm}(\varepsilon 12000) ;{ }^{1} \mathrm{H}$ NMR $\delta 0.02$ (s, 6, $2 \mathrm{x}$ $\mathrm{Me}), 0.85(\mathrm{~s}, 9, t-\mathrm{Bu}), 3.89\left(\mathrm{dd}, J_{5^{\prime \prime}-5^{\prime}}=10.7 \mathrm{~Hz}, J_{5^{\prime \prime}-4^{\prime}}=7.3 \mathrm{~Hz}, 1, \mathrm{H} 5^{\prime \prime}\right), 3.93\left(\mathrm{dd}, J_{5^{\prime}-4^{\prime}}=\right.$ $\left.6.0 \mathrm{~Hz}, 1, \mathrm{H} 5^{\prime}\right), 4.70$ (“dt”, $J_{4-5^{\prime}, 5^{\prime}}=7.4 \mathrm{~Hz}, J_{4^{\prime}-3^{\prime}}=2.5 \mathrm{~Hz}, 1, \mathrm{H} 4^{\prime}$ ), 5.22 (br s, 1, H3'), 5.55 (br s, 1, H1'), 5.70 (br s, 1, H2'), $6.13\left(\mathrm{~d}, J_{5-6}=7.3 \mathrm{~Hz}, 1, \mathrm{H} 5\right), 7.21(\mathrm{~d}, 1, \mathrm{H} 6) 7.52(\mathrm{t}, J=$ $\left.7.9 \mathrm{~Hz}, 2, \mathrm{H}_{\text {arom }}\right), 7.70\left(\mathrm{t}, J=7.4 \mathrm{~Hz}, 1, \mathrm{H}_{\text {arom }}\right), 8.06\left(\mathrm{~d}, J=7.1 \mathrm{~Hz}, 2, \mathrm{H}_{\text {arom }}\right) ;{ }^{13} \mathrm{C}$ NMR $\delta$ $0.50(2 \times \mathrm{Me}), 18.76(t-\mathrm{Bu}), 26.24(t-\mathrm{Bu}), 61.09\left(\mathrm{C} 5^{\prime}\right), 72.63\left(\mathrm{C} 2^{\prime}\right), 77.61\left(\mathrm{C} 3^{\prime}\right), 85.22$ (C4'), 88.82 (C1'), 110.53 (C5), 139.81(C6), 153.51 (C2), 171.35 (C4); MS (CI) m/z 445 $\left(100, \mathrm{MH}^{+}\right)$. Anal. Cald for $\mathrm{C}_{22} \mathrm{H}_{28} \mathrm{~N}_{2} \mathrm{O}_{6} \mathrm{Si}$ (444.56): C, 59.44; H, 6.35; N, 6.30. Found: C, $59.03 ; \mathrm{H}, 6.57 ; \mathrm{N}, 6.30$. 
$1-\left[2,3^{\prime}\right.$-Anhydro-2 ${ }^{\prime}{ }^{18} O$-benzoyl-5'- $O$-(tert-butyldimethylsilyl)- $\beta-\mathrm{D}$ -

xylofuranosyl]uracil (41b)

Treatment of 37 (200 mg, $0.59 \mathrm{mmol})$ with ${ }^{18} \mathrm{O}$-labeled benzoyl chloride (40b) $(0.14 \mathrm{~mL})$ as described for $41 \mathrm{a}$ gave compound $41 \mathrm{~b}(180 \mathrm{mg}$, 68\%) with identical physical and spectroscopic properties except for the mass spectrum: MS (CI) $m / z 447$ $\left(100, \mathrm{MH}^{+}\left[{ }^{18} \mathrm{O}\right]\right), 445\left(16, \mathrm{MH}^{+}\left[{ }^{16} \mathrm{O}\right]\right)$.

$1-\left[2,3^{\prime}\right.$-Anhydro-2' $-{ }^{17} O$-benzoyl-5'-O-(tert-butyldimethylsilyl)- $\beta-\mathrm{D}-$ xylofuranosyl]uracil $(41 \mathrm{c})$

Treatment of $37(1.15 \mathrm{~g}, 3.3 \mathrm{mmol})$ with ${ }^{17} \mathrm{O}$-labeled benzoyl chloride (40c) $(0.5$ $\mathrm{ml})$ as described for $41 \mathrm{a}$ gave compound $41 \mathrm{c}(0.45 \mathrm{~g}, 30 \%)$ with identical physical and spectroscopic properties except for the mass spectrum. MS (CI) $m / z 446$ (100, 446 $\left.\mathrm{MH}^{+}\left[{ }^{17} \mathrm{O}\right]\right), 445\left(77, \mathrm{MH}^{+}\left[{ }^{16} \mathrm{O}\right]\right)$.

1-[2,2'-Anhydro-3'- $O$-benzoyl-5'- $O$-(tert-butyldimethylsilyl)- $\beta$-Darabinofuranosyl]uracil (42a)

Compound $41 \mathrm{a}(100 \mathrm{mg}, 0.22 \mathrm{mmol})$ was placed in a $25 \mathrm{~mL}$ round bottomed flask and heated directly by Bunsen burner under argon for 1 min until the solid melted and turned brown. After cooling, the product was directly chromatographed on a silica gel column. Gradient elution [EtOAc $\rightarrow$ 10\%/S2/EtOAc $\rightarrow \mathrm{MeOH} / \mathrm{S} 2 / \operatorname{EtOAc}(2: 10: 88)$ ] and evaporation of the appropriate fraction $\left(R_{f} 0.75\right.$ in $S 4$; and compound $41 \mathrm{a}$ had $R_{f}$ 0.37) gave compound $42 \mathrm{a}\left(65 \mathrm{mg}, 65 \%\right.$ ) as a white solid: $\mathrm{mp} 224-226{ }^{\circ} \mathrm{C}$; UV $\max 231$ $\mathrm{nm}(\varepsilon 20100), \min 210 \mathrm{~nm}(\varepsilon 9000) ;{ }^{1} \mathrm{H}$ NMR $\delta 0.02$ (s, 6, $\left.2 \times \mathrm{Me}\right), 0.90$ (s, 9, $t$-Bu), 
$3.67\left(\mathrm{dd}, J_{5^{\prime \prime}-5^{\prime}}=11.1 \mathrm{~Hz}, J_{5^{\prime \prime}-4^{\prime}}=4.4 \mathrm{~Hz}, 1, \mathrm{H} 5^{\prime \prime}\right), 3.81\left(\mathrm{dd}, J_{5^{\prime}-4^{\prime}}=5.9 \mathrm{~Hz}, 1, \mathrm{H} 5^{\prime}\right), 4.50$ (“'dt”, $\left.J_{4-5^{\prime}, 5^{\prime \prime}}=4.4 \mathrm{~Hz}, J_{4^{\prime}-3^{\prime}}=2.6 \mathrm{~Hz}, 1, \mathrm{H} 4^{\prime}\right), 5.60\left(\mathrm{~d}, J_{2^{\prime}-1^{\prime}}=5.5 \mathrm{~Hz}, 1, \mathrm{H} 2^{\prime}\right), 5.70$ (br s, 1, $\left.\mathrm{H}^{\prime}\right), 6.08\left(\mathrm{~d}, J_{5-6}=7.4 \mathrm{~Hz}, 1, \mathrm{H} 5\right), 6.42\left(\mathrm{~d}, J_{1^{\prime}-2^{\prime}}=5.7 \mathrm{~Hz}, 1, \mathrm{H} 1^{\prime}\right) 7.42\left(\mathrm{~d}, J_{6-5}=7.4 \mathrm{~Hz}\right.$, 1, H6) $7.50\left(\mathrm{t}, J=7.9 \mathrm{~Hz}, 2, \mathrm{H}_{\text {arom }}\right), 7.65\left(\mathrm{t}, J=7.4 \mathrm{~Hz}, 1, \mathrm{H}_{\text {arom }}\right), 8.05(\mathrm{~d}, J=7.2 \mathrm{~Hz}, 2$, $\left.\mathrm{H}_{\text {arom }}\right) ;{ }^{13} \mathrm{C}$ NMR $\delta-0.50(2 \times \mathrm{Me}), 19.01(t-\mathrm{Bu}), 26.35(\mathrm{t}-\mathrm{Bu}), 63.58\left(\mathrm{C} 5^{\prime}\right), 78.34\left(\mathrm{C}^{\prime}\right)$, $87.38\left(\mathrm{C}^{\prime}\right), 88.77\left(\mathrm{C}^{\prime}\right), 91.18\left(\mathrm{C}^{\prime}\right), 110.59(\mathrm{C} 5), 128.84-134.42\left(\mathrm{C}_{\text {arom }}\right), 160.09(\mathrm{C} 2)$, $165.84\left(\mathrm{C}_{\mathrm{bz}}\right), 170.42(\mathrm{C} 4)$; MS (CI) $m / z 445\left(100, \mathrm{MH}^{+}\right)$. Anal. Cald. for $\mathrm{C}_{22} \mathrm{H}_{28} \mathrm{~N}_{2} \mathrm{O}_{6} \mathrm{Si}$ (444.56): C, 59.44; H, 6.35; N, 6.30. Found: C, 59.80; H, 6.42; N, 6.32.

$1-\left[2,2^{\prime}\right.$-Anhydro-3' $-{ }^{18} O$-benzoyl-5'- $O$-(tert-butyldimethylsilyl)- $\beta$-Darabinofuranosyl]uracil (42b)

Treatment of compound $41 \mathrm{~b}(70 \mathrm{mg}, 0.15 \mathrm{mmol})$ as described for $42 \mathrm{a}$ gave $42 \mathrm{~b}$ (44 $\mathrm{mg}, 63 \%$ ) with identical physical and spectroscopic properties except for the mass spectrum. MS (CI) $m / z 447\left(100, \mathrm{MH}^{+}\left[{ }^{18} \mathrm{O}\right]\right), 445\left(35,445 \mathrm{MH}^{+}\left[{ }^{17} \mathrm{O}\right]\right)$.

1 - $\left[2,2^{\prime}\right.$-Anhydro-3' ${ }^{17} O$-benzoyl-5'- $O$-(tert-butyldimethylsilyl)- $\beta$-Darabinofuranosyl]uracil (42c)

Treatment of compound $41 \mathrm{c}(50 \mathrm{mg}, 0.11 \mathrm{mmol})$ as described for $42 \mathrm{a}$ gave compound $42 \mathrm{c}(27 \mathrm{mg}, 54 \%$ ) with identical physical and spectroscopic properties except for the mass spectrum. MS (CI) $\mathrm{m} / 2446\left(100, \mathrm{MH}^{+}\left[{ }^{17} \mathrm{O}\right]\right), 445\left(85, \mathrm{MH}^{+}\left[{ }^{16} \mathrm{O}\right]\right)$. 


\section{1-(2,2'-Anhydro- $\beta$-D-arabinofuranosyl)uracil (43a)}

Compound $42 \mathrm{a}\left(22 \mathrm{mg}, 0.5 \mathrm{mmol}\right.$ ) was dissolved in a saturated solution of $\mathrm{NH}_{3}$ in $\mathrm{MeOH}(5 \mathrm{~mL})$ and was stirred at $\sim{ }^{\circ} \mathrm{C}$. After $2 \mathrm{~h}$, the reaction mixture was evaporated, and to the white residue $\mathrm{NH}_{4} \mathrm{~F}(28 \mathrm{mg}, 0.75 \mathrm{mmol})$ and anhydrous $\mathrm{MeOH}(5 \mathrm{~mL})$ were added to the white residue. The resulting solution was stirred at room temperature overnight. TLC in S5 showed compound 43a with $R_{f} 0.4$ (compound 42a had $R_{f} 0.75$ ). Volatiles were evaporated, and the residue was purified on RP- HPLC (elution 8\% $\mathrm{CH}_{3} \mathrm{CN} / 92 \% \mathrm{H}_{2} \mathrm{O}$, retention time $25 \mathrm{~min}$.) to give compound $43 \mathrm{a}$ as off-white crystals (8 $\mathrm{mg}, 71 \%$ ): $\mathrm{mp} 244-245^{\circ} \mathrm{C}\left(\right.$ lit. $\left.^{46} \mathrm{mp} 238-244^{\circ} \mathrm{C}\right)$; UV $\max 225,251 \mathrm{~nm}(\varepsilon 7000,5850)$, $\min 237,212 \mathrm{~nm}(\varepsilon 5200,5200) ;{ }^{1} \mathrm{H}$ NMR (DMSO-d $\left.d_{6}\right) \delta 3.16-3.47$ (m, 2, H5',5"), 4.07 $\left(\mathrm{t}, J_{3^{\prime}-2^{\prime}}=4.5 \mathrm{~Hz}, 1, \mathrm{H} 3^{\prime}\right), 4.38\left(\mathrm{~s}, 1, \mathrm{H} 4^{\prime}\right), 4.99\left(\mathrm{t}, J_{5^{\prime}} \mathrm{OH}^{-5^{\prime} / 5^{\prime \prime}}=5.2 \mathrm{~Hz}, 1, \mathrm{OH} 5^{\prime}\right), 5.20\left(\mathrm{~d}, J_{3^{\prime}-}\right.$ $\left.2^{\prime}=5.6 \mathrm{~Hz}, 1, \mathrm{H} 2^{\prime}\right), 5.85\left(\mathrm{~d}, J_{5-6}=7.4 \mathrm{~Hz}, 1, \mathrm{H} 5\right), 5.90\left(\mathrm{~d}, J_{3^{\prime} \mathrm{OH}-3^{\prime}}=4.3 \mathrm{~Hz}, 1, \mathrm{OH} 3^{\prime}\right), 6.31$ $\left(\mathrm{d}, J_{1^{\prime}-2^{\prime}}=5.7 \mathrm{~Hz}, 1, \mathrm{H} 1^{\prime}\right) 7.85\left(\mathrm{~d}, J_{6-5}=7.4 \mathrm{~Hz}, 1, \mathrm{H} 6\right) ;{ }^{13} \mathrm{C}$ NMR (DMSO- $\left.d_{6}\right) \delta$ 61.68(C5'), 75.77(C4'), 89.60(C3'), 90.08(C2'), 90.88(C1'), 109.46(C5), 137.73(C6), 160.66(C2), 172.07(C4); MS (CI) $m / z 227\left(100, \mathrm{MH}^{+}\left[{ }^{16} \mathrm{O}\right]\right)$.

\section{1-(2,2'-Anhydro-3' ${ }_{-}^{18} O-\beta$-D-arabinofuranosyl)uracil (43b)}

Deprotection of compound $\mathbf{4 2 b}(8 \mathrm{mg}, 0.034 \mathrm{mmol}$ ) as described for $\mathbf{4 2 a}$ gave compound 43b (3mg, 73\%) with identical physical and spectroscopic properties except for the mass spectrum: MS (CI) $\mathrm{m} / z 229\left(100, \mathrm{MH}^{+}\left[{ }^{18} \mathrm{O}\right]\right), 227\left(37, \mathrm{MH}^{+}\left[{ }^{16} \mathrm{O}\right]\right)$. 


\section{1-(2,2'-Anhydro-3'- ${ }^{17} O-\beta-\mathrm{D}$-arabinofuranosyl)uracil (43c)}

Deprotection of compound 42c (22 $\mathrm{mg}, .05 \mathrm{mmol})$ as described for 42a gave compound $43 \mathrm{c}$ ( $7.4 \mathrm{mg}, 65 \%)$ with identical physical and spectroscopic properties except for the mass spectrum: MS (CI) $m / z 228\left(98, \mathrm{MH}^{+}\left[{ }^{17} \mathrm{O}\right]\right), 227\left(100, \mathrm{MH}^{+}\left[{ }^{16} \mathrm{O}\right]\right)$.

\section{2'- Azido-2'-deoxyuridine (44a)}

Lithium fluoride (47 mg, $1.8 \mathrm{mmol}$ ) was suspended in DMF $(2 \mathrm{~mL})$, and the resulting suspension was heated to $105{ }^{\circ} \mathrm{C}$ with stirring. Then $N, N, N, N$ tetramethylethylenediamine $(2 \mathrm{~mL})$ was added followed by azidotrymethylsilane $(0.24$ $\mathrm{mL}) .{ }^{37}$ After stirring for $30 \mathrm{~min}$, compound $43 \mathbf{a}(0.226 \mathrm{~g}, 1.0 \mathrm{mmol})$ was added, and the reaction was allowed to proceed for $48 \mathrm{~h}$ at $110^{\circ} \mathrm{C}$ (oil bath temperature). The volatiles were evaporated under vacuum, and the residue was co-evaporated three times with methanol. The residue was dissolved in methanol $(10 \mathrm{~mL})$, and ethyl acetate $(40 \mathrm{~mL})$ was added to precipitate most of the salts and residual starting materials. The filtered solution was applied to a silica gel column and eluted with methanol/ethyl acetate (20/80) to give 44a $(0.22 \mathrm{~g}, 83 \%)$ as a yellowish foam $(0.22 \mathrm{~g}, 83 \%)$. This material was re-purified by RP-HPLC (elution, $\left.15 \% \mathrm{CH}_{3} \mathrm{CN} / 85 \% \mathrm{H}_{2} \mathrm{O}\right)$ to yield pure $44 \mathrm{a}(0.14 \mathrm{~g}, 52 \%$ ) as an offwhite foam: UV $\max 261 \mathrm{~nm}, \min 232 \mathrm{~nm} ;{ }^{1} \mathrm{H}$ NMR (DMSO-d 6 ) $\delta 3.62$ (m, 2, H5'/5"), $3.89\left(\mathrm{~s}, 1, \mathrm{H} 4^{\prime}\right), 4.04\left(\mathrm{~d}, J_{3^{\prime}-2^{\prime}}=5.3 \mathrm{~Hz}, 1, \mathrm{H} 3^{\prime}\right), 4.29$ (' $\left.\mathrm{q}^{\prime}, J_{2^{\prime}-1^{\prime} 3^{\prime}}=5.0 \mathrm{~Hz}, 1, \mathrm{H} 2^{\prime}\right), 5.20$ (t, $\left.J_{5^{\prime} \mathrm{OH}-5^{\prime} / 5^{\prime \prime}}=5.0 \mathrm{~Hz}, 1, \mathrm{OH}^{\prime}\right), 5.68\left(\mathrm{~d}, J_{5-6}=8.0 \mathrm{~Hz}, 1, \mathrm{H} 5\right), 5.87\left(\mathrm{~d}, J_{3^{\prime} \mathrm{OH}-3^{\prime}}=5.4 \mathrm{~Hz}, 1\right.$, OH3'), $5.90\left(\mathrm{~d}, J_{1^{\prime}-2^{\prime}}=5.4 \mathrm{~Hz}, 1, \mathrm{H} 1^{\prime}\right) 7.67\left(\mathrm{~d}, J_{6-5}=8.0 \mathrm{~Hz}, 1, \mathrm{H} 6\right), 11.4(\mathrm{~s}, 1, \mathrm{NH}) ; \mathrm{MS}$ (CI) $m / z 270\left(100, \mathrm{MH}^{+}\left[{ }^{16} \mathrm{O}\right]\right)$. 


\section{$2^{\prime}$-Azido-3'- ${ }^{17} \mathrm{O}-2^{\prime}$-deoxyuridine (44c)}

Treatment of compound $43 \mathrm{c}(50 \mathrm{mg}, 0.22 \mathrm{mmol}$ ) as described for 44a gave compound $44 \mathrm{c}(27 \mathrm{mg}, 45 \%)$ as a yellowish foam. RP-HPLC purification gave compound $44 \mathrm{c}$ as an off-white foam (16 mg, 27\%) with identical physical and spectroscopic properties except for the mass spectrum: MS (APCI) $m / z 271$ (100, $\left.\mathrm{MH}^{+}\left[{ }^{17} \mathrm{O}\right]\right), 270\left(98, \mathrm{MH}^{+}\left[{ }^{16} \mathrm{O}\right]\right)$.

\section{2'-Azido-2'-deoxy-5'-O-(para-toluenesufonyl)uridine (45a)}

$P$-toluenesulfonyl chloride $(21.08 \mathrm{mg}, 0.11 \mathrm{mmol})$ was added to a stirred solution of compound $44 \mathrm{a}(20 \mathrm{mg}, 0.074 \mathrm{mmol})$ in anhydrous pyridine $(1 \mathrm{~mL})$ at ambient temperature. After $14 \mathrm{~h}$ the reaction mixture was evaporated, and the residue was partitioned $\left(0.1 \mathrm{~N} \mathrm{HCl} / \mathrm{H}_{2} \mathrm{O} / / \mathrm{CHCl}_{3}\right)$. The organic layer was washed $\left(\mathrm{NaHCO}_{3}, \mathrm{NaCl}\right)$, dried $\left(\mathrm{MgSO}_{4}\right)$, and evaporated. TLC in S6 showed a small amount of upper moving 3',5'-O-ditosylated compound, but the lower moving 5'-O-monotosylated 45a was the major product. This crude material was chromatographed on a silica gel column. Gradient elution $\left(\mathrm{CHCl}_{3} \rightarrow 5 \% \mathrm{MeOH} / \mathrm{CHCl}_{3}\right)$ and evaporation of the appropriate fractions $\left(\mathrm{R}_{\mathrm{f}}\right.$ for compound $45 \mathrm{a}$ in $\mathrm{S} 6$ was 0.4 and 3',5'-O-ditosylated byproduct had $\mathrm{R}_{\mathrm{f}} 0.6$ ) gave compound 45a (21 mg, $67 \%$ ): UV $\max 226,262 \mathrm{~nm} ;{ }^{1} \mathrm{H}$ NMR $\delta 4.17$ (s, 2, H5'/5"), 4.32 (“t”, $J=11.1 \mathrm{~Hz}, 1, \mathrm{H} 4$ '), 4.36 (br s 1, H3') 4.40 (“'d”, $J=5.5 \mathrm{~Hz}, 1, \mathrm{H} 2$ '), 5.75 (d, $J_{5-6}=$ $8.0 \mathrm{~Hz}, 1, \mathrm{H} 5), 5.88\left(\mathrm{~d}, J_{1^{\prime}-2^{\prime}}=2.8 \mathrm{~Hz}, 1, \mathrm{H} 1^{\prime}\right), 7.41\left(\mathrm{~d}, J=7.6 \mathrm{~Hz}, 2, \mathrm{H}_{\text {arom }}\right) 7.51\left(\mathrm{~d}, J_{6-5}=\right.$ $7.7 \mathrm{~Hz}, 1, \mathrm{H} 6) 7.82\left(\mathrm{~d}, J=7.4 \mathrm{~Hz}, 2, \mathrm{H}_{\mathrm{arom}}\right) 9.24(\mathrm{~s}, 1, \mathrm{NH}) ;{ }^{13} \mathrm{C} \mathrm{NMR} \delta 22.16(\mathrm{Me})$, $66.32\left(\mathrm{C}^{\prime}\right), 67.90\left(\mathrm{C} 3^{\prime}\right) 70.18\left(\mathrm{C} 2^{\prime}\right), \quad 81.65\left(\mathrm{C} 4^{\prime}\right), 88.72\left(\mathrm{C} 1^{\prime}\right), 103.31(\mathrm{C} 5), 128.31$ $\left(\mathrm{C} 3_{\text {arom }}\right) 130.65\left(\mathrm{C} 2_{\text {arom }}\right) 132.43\left(\mathrm{C}_{\text {arom }}\right) 139.68(\mathrm{C} 6), 145.50\left(\mathrm{Cl}_{\text {arom }}\right) 150.51(\mathrm{C} 2)$, 
$163.49(\mathrm{C} 4)$; MS (APCI) m/z $424\left(100, \mathrm{MH}^{+}\left[{ }^{16} \mathrm{O}\right]\right), 425\left(17.5, \mathrm{MH}^{+}\left[{ }^{16} \mathrm{O}\right]+1\right), 426(8$, $\left.\mathrm{MH}^{+}\left[{ }^{16} \mathrm{O}\right]+2\right)$.

\section{$2^{\prime}$-Azido-2'-deoxy-3'- ${ }^{17} O-5^{\prime}-O$-(para-toluenesufonyl)uridine (45c)}

Treatment of compound $44 \mathrm{c}(17 \mathrm{mg}, 0.063 \mathrm{mmol})$ with tosyl chloride as described for 45a gave compound $45 \mathrm{c}(17 \mathrm{mg}, 63 \%)$ with identical physical and spectroscopic properties except for the mass spectrum: MS (APCI) $m / z 424$ (98, $\left.\mathrm{MH}^{+}\left[{ }^{16} \mathrm{O}\right]\right), 425\left(100, \mathrm{MH}^{+}\left[{ }^{17} \mathrm{O}\right]\right), 426\left(45, \mathrm{MH}^{+}\left[{ }^{17} \mathrm{O}\right]+1\right)$.

\section{Preparation of tris(Tetra- $n$-butylammonium) hydrogen Pyrophosphate}

Method A. Tetrasodium pyrophosphate $(1.11 \mathrm{~g}, 2.5 \mathrm{mmol})$ was dissolved in deionised water $(10 \mathrm{~mL})$. The dissolved salt was applied to a column of Dowex $50 \mathrm{~W} \mathrm{x}$ 2-200 $\left(\mathrm{H}^{+}\right)$ion exchange resin $(2 \%$ cross linking, 100-200 mesh, hydrogen form) and eluted with deionised water $(\sim 30 \mathrm{~mL})$. Acidic fractions ( $\mathrm{pH} \sim 1.5)$ were collected, and the resulting solution was neutralized $(\mathrm{pH} \sim 7.3)$ by dropwise addition of a $40 \%$ (wt/wt) solution tetra- $n$-butylammonium hydroxide in water. The neutralized solution was evaporated to yield a viscous, clear syrup, which upon high vacuum drying gave a hygroscopic white solid (2.2 g, 98\%). ${ }^{1} \mathrm{H}$ NMR $\left(\mathrm{D}_{2} \mathrm{O}\right), 0.77(\mathrm{t}, J=7.3 \mathrm{~Hz}, 3 \mathrm{H}), 1.20$ (m, $4 \mathrm{H}), 3.02(\mathrm{t}, J=8.3 \mathrm{~Hz}, 2 \mathrm{H}) ;{ }^{31} \mathrm{P}$ NMR $\left(\mathrm{D}_{2} \mathrm{O}\right)-6.67(\mathrm{~s})$.

Note: Tetrasodium pyrophosphate can be substituted by disodium hydrogen pyrophosphate to give tris(tetra- $n$-butylammonium) hydrogen pyrophosphate ( $97 \%$ yield) with identical spectroscopic characteristics. 
Method B. A $10 \%$ solution $(\mathrm{v} / \mathrm{v})$ of disodium hydrogenpyrophosphate $(3.33 \mathrm{~g}$, $15.0 \mathrm{mmol})$ in aqueous ammonium hydroxide $(15 \mathrm{~mL})$ was passed through a $2.5 \mathrm{~cm} \times 7.0$ $\mathrm{cm}$ column of Dowex 50WX2-200 ion exchange resin (2\% cross linking, 100-200-mesh, hydrogen form). The free acid was eluted with deionised water $(100 \mathrm{~mL})$, and the resulting solution $(\mathrm{pH} \sim 1.5)$ was immediately neutralized to $\mathrm{pH} 7.3$ with aqueous tetra-nbutylammonium hydroxide. The resulting solution (approximately $150 \mathrm{ml}$ total volume) was dried by lyophilization to yield $13.1 \mathrm{~g}(97 \%)$ of a hygroscopic white solid.

\section{2'-Azido-2'-deoxyuridine 5'-diphosphate (46a)}

Compound 45a ( $7 \mathrm{mg}, 0.017 \mathrm{mmol})$ was dissolved in acetonitrile $(0.2 \mathrm{~mL})$ and tris(tetra- $n$-butylammonium) hydrogen pyrophosphate $(25 \mathrm{mg}, 0.028 \mathrm{mmol}$ ), prepared as above, was added in one portion. The reaction mixture was stirred at room temperature for $48 \mathrm{~h}$. Volatiles were evaporated, and the residue was dissolved in water and purified

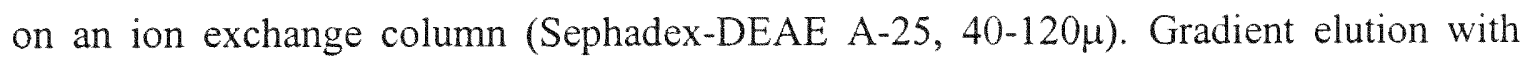
triethylammonium bicarbonate $(0.05 \mathrm{~N} \rightarrow 0.5 \mathrm{~N})$, evaporation of the appropriate fractions, and co-evaporation with $\mathrm{H}_{2} \mathrm{O}$ and $\mathrm{MeOH}$ ( $\mathrm{R}_{\mathrm{f}}$ for compound $46 \mathrm{a}$ in $\mathrm{S} 7$ was 0.6 and compound 45a had $R_{f} 0.8$ ) gave compound $46 \mathrm{a}$ as the triethylammonium salt (4.2 $\mathrm{mg}$, 52\%): UV $\max 261 \mathrm{~nm}, \min 227 \mathrm{~nm} ;{ }^{1} \mathrm{H}$ NMR $\left(\mathrm{D}_{2} \mathrm{O}\right) \delta 4.09$ (m 2, H5'/5"), 4.14 ("t", $J=$ $\left.2.8 \mathrm{~Hz}, 1, \mathrm{H}^{\prime}\right), 4.26\left(\mathrm{t}, J_{3^{\prime}-2^{\prime}}=5.3 \mathrm{~Hz}, 1, \mathrm{H} 3^{\prime}\right) 4.49\left(\mathrm{t}, J_{2^{\prime}-1^{\prime}}=5.0 \mathrm{~Hz}, 1, \mathrm{H} 2^{\prime}\right), 5.84\left(\mathrm{~d}, J_{5-6}=\right.$ $8.1 \mathrm{~Hz}, 1, \mathrm{H} 5), 5.95\left(\mathrm{~d}, J_{1^{\prime}-2^{\prime}}=5.2 \mathrm{~Hz}, 1, \mathrm{H} 1^{\prime}\right), 7.85\left(\mathrm{~d}, J_{6-5}=8.0 \mathrm{~Hz}, 1, \mathrm{H} 6\right) ;{ }^{31} \mathrm{P} \mathrm{NMR}-$ $10.24(\mathrm{~d}, J=19.5 \mathrm{~Hz}),-9.57$ (br s). ${ }^{1} \mathrm{H}$ NMR showed a triplet (1.2 ppm) and a quartet (3.4 ppm) for the triethylammonium counterions, and ${ }^{31} \mathrm{P}$ NMR showed a considerable amount of pyrophosphate impurity $(-9.50 \mathrm{ppm})$ in the product. 
2'-Azido-2'-deoxy-3'-17 $\mathrm{O}$-uridine 5'-diphosphate (46c)

Treatment of compound $45 \mathrm{c}(17 \mathrm{mg}, 0.041 \mathrm{mmol})$ with tris(tetra- $n$ butylammonium) hydrogen pyrophosphate $(54 \mathrm{mg}, 0.06 \mathrm{mmol})$ as described for 46 a gave compound 46c. Purification with ion exchange resin (Sephadex-DEAE A-25, 40-120 $\mu$ ) and co-evaporation with $\mathrm{H}_{2} \mathrm{O}$ and $\mathrm{MeOH}$ gave $46 \mathrm{c}$ ( $8 \mathrm{mg}, 44 \%$ ). This compound was dissolved in water and converted to the sodium salt by passing a solution through a DOWEX $\left(\mathrm{Na}^{+}\right)$column [prepared from DOWEX-50W $\left(\mathrm{H}^{+}\right), 2 \%$-cross linking, 100-200 mesh]. Final purification by RP-HPLC (gradient elution, $3 \% \mathrm{H}_{2} \mathrm{O} / \mathrm{CH}_{3} \mathrm{CN}, \mathrm{R}_{\mathrm{T}}-5.6$ min., semi-prep column, supelcosil LC-18T) gave 46c (4 mg, 22\%) with 50\% pyrophosphate as impurity: ' ${ }^{\mathrm{H}} \mathrm{NMR}\left(\mathrm{D}_{2} \mathrm{O}\right) \delta 4.09$ (m 2, H5'/5"), 4.14 (" $\mathrm{t}$ ”, $\mathrm{J}=2.8 \mathrm{~Hz} 1, \mathrm{H} 4$ '), 4.26 (t, $J_{3^{\prime}-2^{\prime}}$ $\left.=5.3 \mathrm{~Hz}, 1, \mathrm{H} 3^{\prime}\right) 4.49\left(\mathrm{t}, J_{2^{\prime}-1^{\prime}}=5.0 \mathrm{~Hz}, 1, \mathrm{H} 2^{\prime}\right), 5.84\left(\mathrm{~d}, J_{5-6}=8.1 \mathrm{~Hz}, 1, \mathrm{H} 5\right), 5.95\left(\mathrm{~d}, J_{1^{\prime}-2^{\prime}}\right.$ $\left.=5.2 \mathrm{~Hz}, 1, \mathrm{H1} 1^{\prime}\right) 7.85\left(\mathrm{~d}, J_{6-5}=8.0 \mathrm{~Hz}, 1, \mathrm{H} 6\right) ;{ }^{31} \mathrm{P} \mathrm{NMR}-10.17\left(\mathrm{~d}, J=21.1 \mathrm{~Hz}, \mathrm{P}_{\alpha}\right)$, $9.26\left(\mathrm{~d}, J=21.1 \mathrm{~Hz}, \mathrm{P}_{\beta}\right)$. 


\section{CONCLUSION}

Ribonucleotide reductases (RNRs) are enzymes that execute 2'-deoxygenation of ribonucleoside 5'-di and tri-phosphates in unique de novo biosynthetic pathways to DNA monomers. In 1976, it was reported that pyrimidine 2'-azido-2'-deoxynucleotide 5'diphosphates were potent inactivators of ribonucleoside diphosphate reductase (RDPR). Inactivation of RDPR by 2 -azido 2 -deoxynucleosides was accompanied by appearance of a new EPR signal for a nitrogen-centered radical with concomitant decay of the peaks of tyrosyl radical. This nitrogen-centered radical has been characterized by EPR spectroscopy and shown to be composed of a 1:1:1 anisotropic triplet arising from interaction with a single nitrogen and a second hyperfine interaction possibly derived from a proton. The structure of this elusive nitrogen radical has been studied extensively and shown to be derived from the azide moiety. EPR and site-directed mutagenesis studies with the model compounds have led to the conclusion that the nitrogen-centered radical must have the structure $\mathrm{XN}^{\bullet} \mathrm{S}_{\text {cys225 }} \mathrm{R} 1$ in which $\mathrm{X}$ is an oxygen or carbon atom (presumably $3^{\prime}$ ) having no hydrogen attached or with a single hydrogen attached.

The goal of this study was to synthesize $3{ }^{17}\left[{ }^{17} \mathrm{O}\right]-2^{\prime}$-azido-2'-deoxyuridine 5 'diphosphate. Such a labeled analogue should perturb the EPR spectrum of nitrogen centered radical in a predictable fashion, and the hyperfine interaction between the free electron and the ${ }^{17} \mathrm{O}$ nucleus should allow a choice between the recently proposed structures of nitrogen-centered radical by Vander Donk, et al (J. Am. Chem. Soc. 1995, $117,8908)$. In addition, this stereoselective ${ }^{17} \mathrm{O}$-labeling methodology could be employed as a general procedure for the synthesis of $3^{3}\left[{ }^{17} \mathrm{O}\right.$ and $\left.{ }^{18} \mathrm{O}\right]$ labeled pyrimidine nucleosides. 
The labeled 2'-azido-2'-deoxynucleotides were prepared by thermolysis of $O^{2}, 3^{\prime}$ anhydrouridine to give the more stable $O^{2}, 2^{\prime}$-anhydrouridine derivatives with concomitant rearrangement of the $2^{\prime}-O$-benzoyl $\left[{ }^{17} \mathrm{O}\right]$ group into the $3^{\prime}-\left[{ }^{17} \mathrm{O}\right]$-benzoyl intermediate. Deprotection and ring opening with $\mathrm{LiF} / \mathrm{Me}_{3} \mathrm{SiN}_{3}$ gave the $3{ }^{1}\left[{ }^{17} \mathrm{O}\right]-2^{\prime}$-azido2'-deoxyuridine. Tosylation (O5') and displacement of the 5'-tosylate by treatment with tris(tetra- $n$-butylammonium) hydrogen pyrophosphate gave $3^{\prime}\left[{ }^{17} O\right]-2^{\prime}$-azido-2'deoxyuridine 5 '-diphosphate. All intermediates and products were characterized by ${ }^{\prime} \mathrm{H}$ NMR, ${ }^{13} \mathrm{C}-\mathrm{NMR},{ }^{31} \mathrm{P}-\mathrm{NMR}$, and isotopic enhancement was confirmed by using mass spectrometry. 


\section{REFERENCES}

1. Miesher, F. Hoppe-Seyers 's Med Chem. Unters. 1871, 441.

2. Altmann, R. Arch. Ana. U. Physiol., Physiol. Abt. 1899, 524.

3. Voet, D.; Voet, G. J. Biochemistry 1990, John Wiley \& Sons.

4. Solomon G. Organic Chemistry $1994,6^{\text {th }}$ edition, John Wiley \& Sons.

5. Blackburn, M. G.; Gait, J. M. Nucleic Acids in Chemistry and Biology 1997, $2^{\text {nd }}$ edition, Oxford University Press.

6. Watson, J. D.; Crick. F. H. C. Nature 1953, 171, 737 and 964.

7. Carey A. Francis, Organic Chemistry 1987, McGraw-Hill Book Company.

8. Silverman, R. B. Mechanism-Based Enzyme Inactivation: Chemistry and Enzymology, CRC Press: Boca Raton, FL, 1988; pp. 3-30.

9. Ashley, G. W.; Stubbe, J. In Inhibitors of Ribonucleoside Diphosphate Reductase Activity, International Encyclopedia of Pharmacology and Therapeutics, Section 128, Cory, J. G.; Cory, A. H., Eds.; Pergamon Press: New York 1989; pp. 55-87.

10. Jordan, A.; Reichard, P. Annu. Rev. Biochem. 1998, 67, 71-98.

11. Stubbe, J.; Vander Donk, A. W. Chem. Biol. 1995, 2, 793

12. Stubbe, J. J. Biol. Chem. 1990, 265, 5329-5332.

13. Stubbe, J. Adv. Enzymol. Relat. Areas. Mol. Biol. 1990, 63, 349-417.

14. Thelander, L.; Reichard, P. Ann. Rev. Biochem. 1979, 48,133-158.

15. Nordlund, P.; Sjöberg, B. -M.; Eklund, H. Nature 1990, 345, 593-598.

16. Reichard, P.; Ehrenberg, A. Science 1983, 221, 514-519.

17. Ehrenberg, A.; Reichard, P. J. Biol. Chem. 1972, 247, 3485-3488.

18. Stubbe, J.; Ator, M.; Krenitsky, T. J. Biol. Chem. 1983, 258, 1625-1630.

19. Nord, F. F.; Meister, A. In Advances in Enzymology and Related Areas of Molecular Biology, Vol. 63, Stubbe, J., Eds.; John Wiley \& Sons, New York 1990, p. 367. 
20. Siegbahn, P. E. M. J. Am. Chem. Soc 1998, 120,8417-8429.

21. Lenz, R.; Giese, B. J. Am. Chem. Soc. 1997, 119, 2784-2794.

22. Robins, J. M.; Guo, Z.; Samano, C. M.; Wnuk, F. S. J. Am. Chem. Soc. 1999, 121 1425-1433.

23. Guo, Z.; Samano, C. M.; Krzykawski, W. J.; Wnuk, F. S.; Ewing, J. G.; Robins, J. M. Tetrahedron 1999, 55, 5705-5718.

24. Thelander, L.; Larson, B.; Hobbs, J.; Eckstein, F. J. Biol. Chem. 1976, 251, 19381405.

25. Sjöberg, B. -M.; Graslund, A.; Eckstein, F. J. Biol. Chem. 1983, 8060-8067.

26. Ator, M.; Salowe, S. P.; Stubbe, J.; Emptage, M. H.; Robins, M. J. J. Am. Chem. Soc. 1984, 106, 1886-1887.

27. Salowe, S. P.; Ator, M. A.; Stubbe, J. Biochemistry 1987, 26, 3408-3416.

28. Salowe, S. P.; Bollinger, J. M. Jr.; Ator, M.; Stubbe, J.; McCrracken, J.; Peisach, J.; Samano, M. C.; Robins, M. J. Biochemistry 1993, 32, 12749-12760.

29. Behravan, G.; Sen, S.; Rova, U.; Thelander, L.; Eckstein, F.; Gräslund, A. Biochim. Biophys. Acta 1995, 1264, 323-329.

30. Vander Donk, W. A.; Stubbe J.; Gerfen, G, J.; Bellew, B. F.; Griffin, R. G. J. Am. Chem. Soc. 1995, 117, 8908-8916.

31. Caprioli, R.; Rettenberg, D. Biochemistry 1969, 8, 3375.

32. Follman, H.; Hogencamp. H. P. C. J. Am. Chem. Soc. 1970, 92, 671.

33. Watanabe, K. A.; Chu, C. K.; Reichman, U.; Fox, J. J. Nucleic Acid Chemistry, Part 1, Townsend, L.B. and Tripson, R. S.; Eds, Wiley-Interscience, New York, 1978. p. 343.

34. Solsten. T. R.; McCloskey A. J.; Schram. H. K. Nucleosides and Nucleotides 1982, I, 57-64.

35. Pang, H.; Schram, H. K.; Smith, L. D.; Gupta, S. P.; Townsend, L. B. ; McCloskey A. J. J. Org. Chem. 1982, 47, 3923-3932.

36. Yang, C. N.; Fox, J. J. J. Am. Chem. Soc. 1961, 83, 3060-3066.

37. Todd, D. N.; David, R. C. Synthesis 1996, 9, 1031-1069. 
38. Kocienski, J. P. Protecting Groups 1994, Georg Thieme Verlag Stuttgart. New York.

39. March J. Advanced Organic Chemistry $1992,4^{\text {th }}$ edition, John Wiley \& Sons.

40. Zhang, W.; Robins, J. M. Tetradedron Lett. 1992, 33, 1177-1180.

41. Hampton, A.; Nicol, A. W. Biochemistry, 1966, 5, 2076-2082.

42. Verheyden, J. P. H; Wagner, D.; Moffatt, G. J. Org. Chem. 1971, 36, 250-253.

43. Kirschenbenter, P. G.; Zhai, Y.; Picken, A. W. Tetrahedron Lett. 1994, 95, 85178520.

44. Yoshikawa, M.; Tetsuya K.; Takenishi, T. Tetrahedron Lett. 1967, 50, 5065-5068.

45. Davisson V. J.; Darrel R. D.; Dixit, M. Vyas.; Poulter, D. C. J. Org. Chem. 1987, 52, 1794-1801.

46. Levene, P. A.; Tipson, R. S. J. Biol. Chem. 1934, 105, 419. 